\title{
Advances in metal-based vanadate compound photocatalysts: synthesis, properties and applications
}

\author{
Asieh Akhoondi ${ }^{\text {a,*}, ~ U s i s i p h o ~ F e l e n i ~}{ }^{\text {b }}$, Bhaskar Bethi ${ }^{\text {c }}$, Azeez Olayiwola Idris ${ }^{\text {b }}$, \\ Akbar Hojjati-Najafabadi ${ }^{\text {d,e }}$ \\ ${ }^{a}$ Department of Chemical Engineering, Arak Branch, Islamic Azad University, Arak, Iran \\ ${ }^{b}$ Institute for Nanotechnology and Water Sustainability (iNanoWS), Florida Campus, College of Science, Engineering and Technology, University of \\ South Africa, Johannesburg 1709, South Africa \\ ${ }^{c}$ Department of Chemical Engineering, B. V. Raju Institute of Technology, Narsapur, Medak (Dist.), Telangana State, India \\ ${ }^{d}$ College of Rare Earths, Jiangxi University of Science and Technology, No.86, Hongqi Ave., Ganzhou, Jiangxi, 341000, PR China \\ ${ }^{e}$ Faculty of Materials, Metallurgy and Chemistry, School of Materials Science and Engineering, Jiangxi University of Science and Technology, Ganzhou, \\ 341000, PR China
}

\section{A B S T R A C T}

\begin{abstract}
Among the ongoing research on photocatalysis under visible-light, it has been shown that doped or hybrid catalysts are more active than a single catalyst alone. However, problems including visible light absorption, a low quantity of energetic sites on surfaces, and rapid recombination of the photo-electron hole pair produced by light have prohibited photocatalysts from being used in a practical and widespread manner. To overcome these problems, synthesis of nanostructure hybrid catalyst using several methods has attracted much attention. Several procedures have been suggested for the preparation of photocatalysts with the desired structure and morphology. Preparation methods similar to partial modification may lead to diverse structures and qualities. In this regard, the development of efficient, low-cost photocatalysts and rapid synthesis is the most important issues that should be considered. This review discusses various methods and mechanisms that work with the modification of vanadium compounds as photocatalysts to progress their photocatalytic efficiency. In addition, the effects of synthesis temperature, solution $\mathrm{pH}$ and concentration on the photocatalytic performance are also described in detail.
\end{abstract}

(C) 2021 The Authors. Published by Synsint Research Group.

\section{KEYWORDS}

\section{Photocatalyst}

Synthesis

Solar energy

Structure

Visible-light

Vanadium

\section{Introduction}

Many problems, such as environmental pollution and insufficient energy resources, have forced scientists to find appropriate solutions. The technology of using photocatalysts is one of the new solutions that have been welcomed in developed countries. Photocatalysis process involves reactions that occurs using light and semiconductors which has recently attracted much attention. Solar energy is a readily available and free resource that may be used to deliver energy to industries as a viable alternative to fossil fuels. Other technologies, such as photocatalysis, photovoltaics, smart materials and environmental purification, have been used with solar energy [1-4] The production of hydrocarbon fuel such as methanol and dimethyl ether by photocatalysis technology has been studied in last decade [5] Carbon dioxide $\left(\mathrm{CO}_{2}\right)$ activation by photoreduction to methane $\left(\mathrm{CH}_{4}\right)$ under visible light illumination [6] is the newest photocatalysis techniques without releasing toxic byproducts [7]. The elimination of

* Corresponding author. E-mail address: asieh.akhoondi@gmail.com (A. Akhoondi)

Received 26 August 2021; Received in revised form 17 September 2021; Accepted 24 September 2021.

Peer review under responsibility of Synsint Research Group. This is an open access article under the CC BY license (https://creativecommons.org/licenses/by/4.0/). https://doi.org/10.53063/synsint.2021.1344 


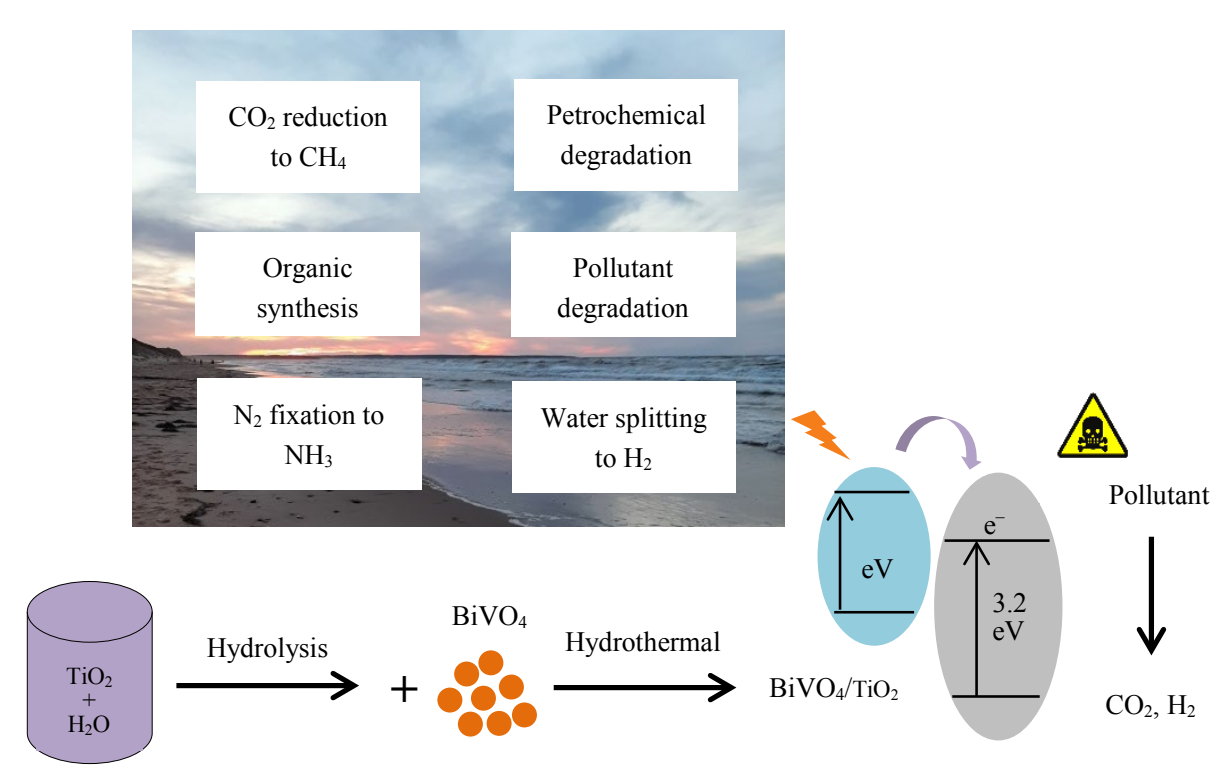

Fig. 1. Photocatalyst applications.

halogenated organic compounds and other volatile organic compounds (VOCs) from water using photocatalysis can be used effectively [8]. Personal care products and pharmaceuticals as emerging contaminants are present in surface water and wastewater, groundwater and even drinking water have been treated effectively using various photocatalysts [9]. Photocatalysts are the best platform for chemical reactions that are normally either difficult or impossible to occur [10]. The increasing development of photocatalysts has grown exponentially in recent years, and its applications can be seen in a wide range of research in Fig. 1.

The main difference between these types of catalysts and conventional heat catalysts is that heat catalysts are activated by heat and accelerate the reaction, while photocatalysts are activated by photons and light energy. These materials absorb sun light to provide higher energy to perform such reactions [11]. In photocatalysts, the main factor of photocatalytic activity (PCA) is the ability of the catalyst to form electron-hole pairs that produce free radicals and are capable of secondary reactions. Photocatalysts are able to decompose harmful substances in the sun containing UV rays [12]. Understanding and optimizing the properties of existing photocatalysts will increase the exploitation of these materials. Despite more than four decades of continuous effort, research in the field of photocatalytic materials is still in its infancy and photocatalytic expansion is still a challenge because of the weak oxidation capacity and the inadequate amount of active sites. Currently, $\mathrm{TiO}_{2}$ is often used as a photocatalyst because of its high oxidation and reduction ability compared to semiconductors such as $\mathrm{WO}_{3}, \mathrm{ZnO}, \mathrm{ZnS}, \mathrm{SrO}_{2}, \mathrm{CdS}$ and $\mathrm{F}-\mathrm{TiO}_{2}$, as well as $\mathrm{TiO}_{2}$ polymorphism, the anatase phase has the most photocatalytic performance [13]. Superoxide $\left(\mathrm{O}^{2^{*}-}\right)$ radicals, hydroxyl radicals $\left({ }^{\circ} \mathrm{OH}^{-}\right)$ and $\mathrm{H}^{+}$holes are responsible for catalyzing the oxidation reactions produced by $\mathrm{TiO}_{2}$ and other photocatalysts (Fig. 2). In semiconductors, the band gap contains energy levels to which valence electrons cannot be promoted [14]. This band is much smaller in semiconductors than in non-conductors. This allows the capacitance layer electrons in semiconductors to be easily transmitted to the conduction band by the application of heat or light. This property makes multiple applications for semiconductors predictable. The reason for the popularity of $\mathrm{TiO}_{2}$ is its low price, high stability, natural abundance, excellent optical properties and environmental friendliness [15]. A desirable photocatalyst should have high surface area, resistant to photocorrosion, thermal and optical stable, narrow band gap energy, high mechanical strength, non-toxic and so on. In addition to $\mathrm{TiO}_{2}, \mathrm{ZnO}$ has been investigated due to its morphology and catalytic structure [16]. In the design of new photocatalysts, goals such as preventing the recombination of electron hole pairs and improving the absorption of light in the visible confine should be considered. In addition, another approach can be mentioned that expanding the edge of photocatalytic light sorption prevents the recombining of electron/hole pairs and increases the photocatalytic efficiency [17]. $\mathrm{TiO}_{2}$ is synthesized in various forms such as nanotubes, nanorods, nanowires, etc. and can be mixed with $\mathrm{CeO}_{2}$ [18], $\mathrm{Fe}_{2} \mathrm{O}_{3}$ [19], $\mathrm{SiO}_{2}$ [20], $\mathrm{AgVO}_{3}$ and $\mathrm{Ag}_{3} \mathrm{VO}_{4}$ [21], $\mathrm{BiVO}_{4}$ [22], $\mathrm{ZnBi}_{2} \mathrm{O}_{4}$ [23]. Zeolites are also used as supporting materials due to consequently their large surface area and porous structure and, high heat adsorption, maintaining structural stability, acidic form and adjustable acidity that can decrease the electron/hole pair recombination [24].

Photocatalytic processes are generally divided into homogeneous and heterogeneous categories [25] and all photocatalysts are essentially semiconductors. In this regard, semiconductors operate in three main stages of the catalytic process, which takes place in heterogeneous operations: 1) Excitation of the bond to form an electron-hole pair, 2) transfer of charge carriers to the photocatalyst surface; and 3) creating energetic sites for the next oxidation and reduction action [26]. Therefore, the electronic structure, bulk structure and surface structure of photocatalysts strongly affect the photocatalytic performance. This means that photocatalysts must have a narrow bandgap and intense oxidation and reduction capabilities. The first case shows that a small band can increase the photo-responsiveness of catalysts for a wider 


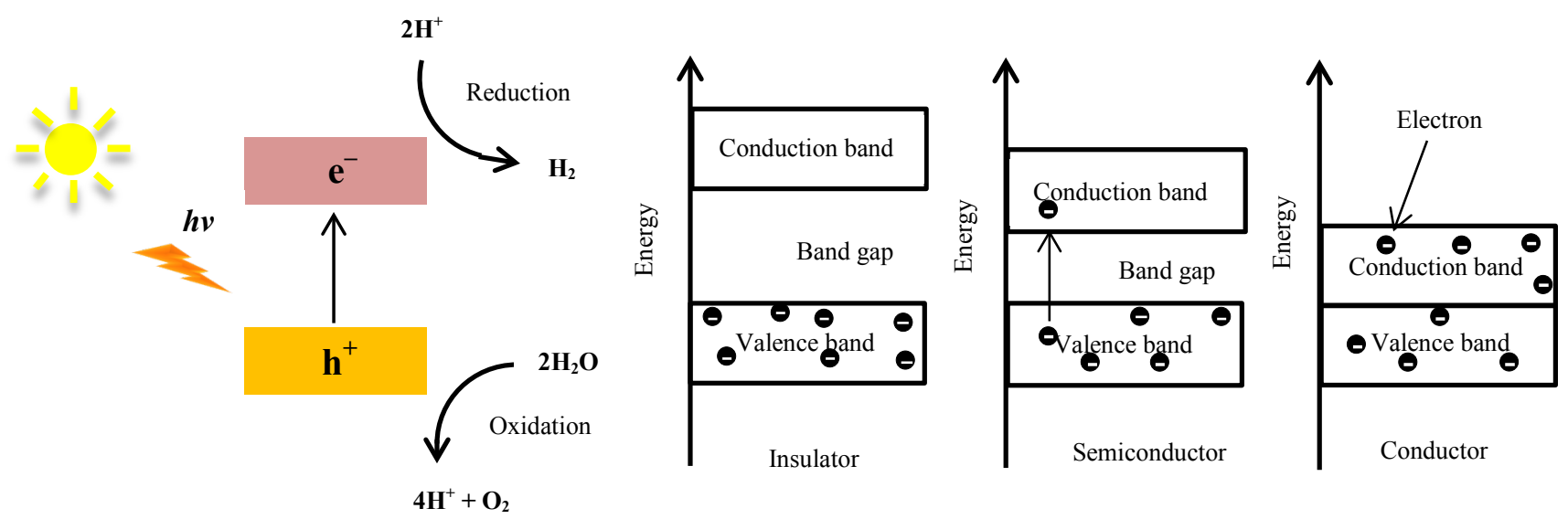

Fig. 2. Schematic of photocatalytic process and different types of materials on the basis of band gap.

range of sunlight usage. Since the photodegradation is proportional to the load on the catalyst in heterogeneous photocatalytic reactions, the optimum photocatalyst concentration must be determined to prevent the use of extra photocatalyst [27]. The efficiency of photocatalysts are affected by co-catalysts morphology, degree of crytallinity, specific surface area (SSA) and surface acidity, so it should be expanded in this field. The specific surface area of a photocatalyst depend on the porosity, pore size distribution, shape and roughness. Vanadate-base compounds are widely used in photocatalysis process due to their fascinating features but there are some challenges such as high band gap energy, reusability, fast electron/hole pair recombination rate and poor activity in visible light [28]. In this regard, a group of vanadate composites $\left(\mathrm{M}^{3+} \mathrm{VO}_{4}\right)$, where $\mathrm{M}^{3+}$ is +3 charge metal cation such as $\mathrm{Fe}^{3+}, \mathrm{In}^{3+}$, and $\mathrm{Ag}^{3+}$ have been summarized. This study provides new insights into the use of vanadium compounds in the synthesis of welldefined photocatalysts with excellent performance to increase photocatalytic efficiency to remove contaminants, splitting water and hydrocarbon production and so on. The crystal constructions and the optical features of photocatalysis are briefly investigated.

\section{Synthesis strategies}

Photocatalytic performance depends greatly on the adsorption properties of the photocatalyst. There are several methods for preparing metal oxide nanoparticles. Methods such as co-precipitation, solid state synthesis, microwave synthesis, hydrothermal method, electrochemical, sol-gel technique, thermal decomposition procedure, arc discharge method, etc. are used for this purpose.

\subsection{Precipitation method}

Among the available techniques, the precipitation method is the simplest and cost-effective concept, because it does not need high pressure and high temperature. The particle structure and crystalline size can be easily changed by moderating the $\mathrm{pH}$ of medium and high samples can be prepared at the same time [29]. During precipitation method, the raw materials must be mixed in a solution to form the desired sediment, and parameters such as temperature and aging time must be optimized in the desired amount to achieve the required precipitate. In this process, a solution containing a precipitating substance, usually hydroxide, is mixed with a solution containing the desired oxide cation. Then the sediments are fired (vanadate, hydroxide, or carbonate). Chemical precipitation methods contain homogeneous precipitation, direct precipitation and co-sedimentation. Preparation of photocatalyst with this method is often used for nanoscale synthesis [30]. The difference between these methods is in the number of cations. If there is only one cation in the solution, it is called the direct precipitation process, while for the co-precipitation procedure; there are several cations in the mixture. Also, coprecipitation and hydrolysis method can be used for uniform distribution of nanomolite powders $(\sim 100 \mathrm{~nm})$. Compared to direct precipitation and co-sedimentation techniques, homogeneous precipitation has advantages of good homogeneity of core and precipitation. Usually a substance is used as a precipitating agent in the homogeneous precipitation process [31].

The efficiency of a chemical precipitation process depends on several parameters such as the type and concentration of ionic metals present in the solution, the precipitate used, the reaction conditions (mostly the acidity of the solution) and the presence of other components that may prevent the precipitation reaction. The precipitation method has advantages such as simplicity, reproducibility, low cost, and ability to modify the surface chemistry which in this regard can be used in the production of large-scale photocatalysts [32]. However, the aging of the sediment often takes more than 24 hours and the weakness of this method is time consuming. By modifying the synthesis conditions, the properties of the products can be controlled. The ratio of raw materials can have a small impact the crystallinity, particle size, band gap and ability to absorb light [33].

The co-precipitation technique is most widely used to prepare a uniform mixture of two or more uniform blends via the precipitation operation, which is one of the great routs for the preparation of nanosized compounds including two or more types of cation in the form of hydroxide, carbonates, oxalates, or citrates [34]. Then, by calcining these precipitates at suitable temperatures, the required nano-powder is obtained. Because the required calcination temperature is low, sedimentation leads to smaller particle sizes. However, in each synthesis specific conditions and different precursor reactions are used. 
Through the co-precipitation technique, homogeneous nanocomposites with uniform distribution can be achieved by various chemical reactions in solution [35].

\subsection{Microwave/ultrasonic-assisted synthesis}

High-intensity ultrasound can be used to produce new material, providing an unusual path for known material without high temperature, high pressure, or long reaction time [36]. In this method, the interaction between molecules occurs with electromagnetic radiation and the electromagnetic energy is converted into thermal energy. This technique can be used as an efficient and harmless technique for synthesizing materials. Acoustic cavities can be created by ultrasonic waves, and this phenomenon in the production and modification of nanomaterials has been able to produce photocatalysts with efficient structures. This idea evaluates the benefits, challenges, and future prospects of metal-based photocatalysts with the aim of degrading pollutants.

\subsection{Hydrothermal and solvothermal method}

Hydrothermal synthesis can be considered as a technique for preparing water-soluble crystals in hot and pressurized water in a crystallization vessel called autoclave made of stainless steel. The hydrothermal method can be used to produce crystals that are not stable at the melting point. It is also useful for producing materials with high vapor pressures at their melting points because the reactions take place in an aqueous medium. The hydrothermal technique has been expanded for the synthesis of highly crystalline nanomaterials. Influential parameters in this method include the type and concentration of raw materials, solvents, stabilizing agents and reaction temperature and time, which have an important effect on product quality. With this method, large crystals with good quality can be produced in one-step process and at the same time their composition ratio can be controlled. This is one of the advantages of the hydrothermal method compared to the coprecipitation method, which is performed at low temperatures and usually produces weak crystalline nanoparticles, but hydrothermal methods have relatively low product yields [37]. Also, the need for costly sealed autoclaves lined with Teflon and the impossibility of observing the crystal as it grows if steel pipes are used are among the disadvantages of the hydrothermal method. Some materials prepared by hydrothermal method have higher photocatalytic degradation efficiency, for example, $\mathrm{BiPO}_{4}$ prepared by hydrothermal synthesis has been reported to possess high efficiency of the optical holes in the capacitance band. Photocatalytic synthesis of these materials by hydrothermal method shows better performance in photodegradation of contaminants compared to non-hydrothermal process [38].

The production of semiconductor nanomaterials through solvothermal roots is an ideal synthesis method. Reaction temperature, $\mathrm{pH}$ and additives, aging time, morphology, crystalline phase and particle size of products are controlled by adjusting solvents. This method is one of the important solutions for the synthesis of bismuth-based photocatalysts [39] with exposed active agents, 3D hierarchical microstructures and surface defects. Generally, photocatalysts prepared using the solvothermal method execute better and are more acceptable for specialized applications than other methods. But low production due to long synthesis time and batch characteristics because of the use of special autoclaves is the main weakness of this method.

\subsection{Sol-gel method}

In chemistry, the sol-gel operation is a way of synthetic approaches to producing high quality solids such as MONPs (metal oxide nanoparticles) as well as mixed oxide composites from micro and nano molecules. This method, which is performed in five stages including hydrolysis, multiple compaction (condensation), aging \& drying (supercritical, thermal or freeze drying) and thermal separation, has extraordinary control over the contexture and surface quality of the final product [40]. The sol-gel method has the advantages of short soaking times, high purity of products, low reaction temperature, and high stability, and is considered as one of the promising methods for artificial photocatalysts. Additionally, the photocatalytic ingredients prepared by the sol-gel method usually have thermal stability and uniform distribution. Consequently, sol-gel technique has attracted much attention in the synthesis of vanadate-based photocatalysts [41].

\section{Metal-based vanadate photocatalysts}

Vanadate is a compound consisting of vanadium oxyanion, which is usually in the maximum oxidation state of +5 . So far, many applications have been found for ternary vanadate one-dimensional, including the production of lithium batteries, electrochemical sensors and photocatalytic process as well as its good electrochemical and photocatalytic properties [42, 43]. Vanadates have attracted a lot of attention in photocatalysis applications due to their attractive structural features. Vanadates are especially described with a close band gap and simple preparation methods [44]. A layered vanadium type such as $\mathrm{BiVO}_{4}$ has attracted considerable attention as a photocatalyst with the help of visible light. There are many semiconductors that have a high ability to absorb visible light [45], but among them, bismuth vanadate $\left(\mathrm{BiVO}_{4}\right)$, which has band gap of $2.4-2.5 \mathrm{eV}$, due to its controllable crystalline aspect and specific electronic structure, has excellent potential for organic degradation and water oxidation. However, the photocatalytic efficiency of $\mathrm{BiVO}_{4}$ is still relatively weak because of slow oxidation of water, the low electron transfer rate, poor mobility of the charge carrier and poor surface adsorption content [46]. Therefore, various solutions to progress its photocatalytic efficiency have been investigated, such as morphological engineering [47], primary doping, defect formation and semiconductor bonding and so on.

$\mathrm{BiVO}_{4}$ is much more efficient than $\mathrm{TiO}_{2}$ because it absorbs more light content due to the $\mathrm{TiO}_{2}$ surface area, which is about 0.1 that of $\mathrm{BiVO}_{4}$ nanocrystals. Loading platinum nanoparticles on the surface of $\mathrm{BiVO}_{4}$ can help as an excellent charge collector and transporter, preventing the recombining of electron-generated hole pairs and eliminating more active sites in the procedure [48]. Moreover, additional acceleration on the electron is made possible by the Schottky energy barrier with loading $\mathrm{Pt}$ on the surface of the particles, hence increasing the hydroxylation reaction at the photocatalyst surface. It is widely accepted that the photocatalytic process in semiconductors is accompanied by the absorption of photons directly through the band gap to excite electrons from the valence band to the conduction band in the particles, and then the holes and separated electrons are transferred to the particle outside. This process begins with the light absorption with energy equitable to or higher than the energy of the semiconductor band gap. It means that the activator of the photocatalyst is a narrow band gap. The branched $\mathrm{BiVO}_{4}$ nanocrystalline photocatalytic particles have band gap energy of approximately $2.5 \mathrm{eV}$ while a titania band gap 
energy of $3.7 \mathrm{eV}$. The narrower $\mathrm{BiVO}_{4}$ band gap compared to titanium makes the excitation of $\mathrm{BiVO}_{4}$ electrons from the capacitance band to the conduction band better by absorbing visible light as well as ultraviolet light and making solar energy more efficient [49]. Electrons are excited by visible light irradiation from the valence band (VB) to the conduction band $(\mathrm{CB})$, creating electropositive holes in the valence band. Then, by transferring the generated holes and electrons to the outside of the $\mathrm{BiVO}_{4}$ nanostructures, the reaction with $\mathrm{O}_{2}$ and water takes place and ${ }^{\circ} \mathrm{O}^{2-}$ and ${ }^{\circ} \mathrm{OH}$ radicals are produced, respectively. In this process, electrons and holes first migrate in two different ways: (1) electrons produced by light are trapped in mastoids or surface pores and transferred to platinum nanocrystals through the Schottky barrier through additional haste. As a result of this extra force, the electrons can quickly combine with oxygen to create ${ }^{\circ} \mathrm{O}^{2-}$ radicals. (2) The photogenerated holes migrate on the nanocrystals surface mastoids, respectively, and then combine with water to form ${ }^{\circ} \mathrm{OH}$ radicals. The produced ${ }^{\circ} \mathrm{OH}$ and ${ }^{\circ} \mathrm{O}^{2-}$ radicals react mostly in $\mathrm{H}_{2} \mathrm{O}$ to break down ciprofloxacin particles into $\mathrm{H}_{2} \mathrm{O}$ and $\mathrm{CO}_{2}$ or further intermediates [50]. However, the complicated mechanism of this reaction for the photodegradation procedure of ciprofloxacin is not fully understood.

Singh et al. showed how to use the thin structure of bismuth vanadate and titanium dioxide as an efficient photocatalyst to photogenerate electron hole pairs and to achieve corrosion resistance, both of which factors are important prerequisites for a photoelectrode to attain high photoelectrochemical performance [22]. By using the thin structure of $\mathrm{BiVO}_{4}$ and $\mathrm{TiO}_{2}$ as photocatalysts and hydrogen purification, a significant improvement in the optical density of tape engineering can be achieved. The increase in photoelectrochemical performance is due to the facilitation of the hole transfer to the electrode surface and the increase in light absorption in the $\mathrm{TiO}_{2}$ substrate [51]. This is an example of how hydrogenation can be used to create the structural properties of $\mathrm{BiVO}_{4} / \mathrm{H}_{\mathrm{TiO}}$, leading to improvements in similar compounds [52].

Due to defects in the one-component photocatalytic structure, comprehensive attempts have been made over the years to configure photocatalysts, for example, to form heterogeneous type-II nanocomposites using two or three semiconductors to enhance charge separation and increase photocatalytic efficiency [53]. The construction of a suitable heterojunction photocatalytic compound can separate electrons and holes in two different places, which in turn increases the lifespan of photogenerated carriers. $\mathrm{Ag}_{3} \mathrm{PO}_{4}$ is a hopeful photocatalyst because its band gap energy is placed in the visible light span ( $\mathrm{Eg} \sim 2.4$ $\mathrm{eV}$ ), so it is a good alternative for replacing titania which is active only under ultraviolet light [54]. Since the crystal aspect is related to the semiconductor photocatalytic efficiency, a new $\mathrm{BiVO}_{4} / \mathrm{Ag}_{3} \mathrm{PO}_{4} /$ polyaniline polymer photocatalyst with heterojunction system aspect has been investigated by Chen et al. [55]. The preparation method of this photocatalyst is the precipitation of $\mathrm{Ag}_{3} \mathrm{PO}_{4}$ in the most active form of $\mathrm{BiVO}_{4}$ and then the combination of polyaniline polymer (PANI). Since morphological engineering can reach active face selective exposure, and heterojunction fabrication can significantly increase the efficiency of singular semiconductor charge separation, heterojunction engineering and simultaneous morphology modification are thought to be a practical strategy for potentially improving photocatalytic efficiency. $\mathrm{Ag}_{3} \mathrm{PO}_{4}$ with high quantum efficiency in sunlight is a suitable semiconductor for photocatalytic decomposition of organic contaminants, because of its intense oxidizing capability of VB holes [56, 57]. But photo corrosion under visible light and dissolution in aqueous solution seriously impede its widespread use. Theoretically, the selective deposition of cocatalysts on $\mathrm{BiVO}_{4}$ could improve photocatalytic performance because of the highly active shape providing more $\mathrm{BiV}_{4}$ polyatomic orbits that could be used as multiple electron transition channels and energetic sites. By analyzing the energy level, it was found that the gap between $\mathrm{CB}$ of $\mathrm{BiVO}_{4}$ and $\mathrm{CB}$ of $\mathrm{g}-\mathrm{C}_{3} \mathrm{~N}_{4}$ (energy band gap of $\sim 2.74 \mathrm{eV}$ ) is much great, positively impacting the recombination of $\mathrm{e}^{-} / \mathrm{h}^{+}$(electron/hole) [58]. This would cause photoinduced electrons in $\mathrm{CB}$ of $\mathrm{BiVO}_{4}$ to be rapidly transferred to valence band of $\mathrm{g}_{-} \mathrm{C}_{3} \mathrm{~N}_{4}$, leaving rich electrons in $\mathrm{CB}$ of g- $\mathrm{C}_{3} \mathrm{~N}_{4}$ and holes in $\mathrm{VB}$ of $\mathrm{BiVO}_{4}$ to take part in the redox action. Therefore, it may lead to an unmediated direct Z-scheme photocatalytic series [59]. The direct Z-scheme of $\mathrm{BiVO}_{4} / \mathrm{g}-\mathrm{C}_{3} \mathrm{~N}_{4}$ results in highefficiency separation of electrons and photogenerated holes, therefore greatly improving photocatalytic efficiency. This general strategy can be used to design other high-performance Z-scheme direct photocatalysts. The results showed that the direct Z-scheme of $\mathrm{BiVO}_{4} / \mathrm{g}-\mathrm{C}_{3} \mathrm{~N}_{4}$ affects the charge separation, and results in significant photocatalytic activity for $\mathrm{BiVO}_{4} / \mathrm{g}-\mathrm{C}_{3} \mathrm{~N}_{4}$ composites under visible light illumination. Therefore, it provides very powerful oxidation and reduction ability. Another study found that $3 \mathrm{D} \quad \mathrm{g}-\mathrm{C}_{3} \mathrm{~N}_{4}$ showed increased exciton resolution, better mobility and separation of charge carriers than $\mathrm{g}-\mathrm{C}_{3} \mathrm{~N}_{4}$ nanosheets, which implies the way for more electron transport in 3D morphology [60]. In particular, g- $\mathrm{C}_{3} \mathrm{~N}_{4}$ nanosheets had a notably reduction in activity (less than $44 \%$ ) because of the accumulation of nanosheets, while $3 \mathrm{D} \mathrm{g}-\mathrm{C}_{3} \mathrm{~N}_{4}$ did not show significant inactivation, which confirms its high stability for the overall water splitting reaction [61]. In another study by Nguyen et al., the effect of $\mathrm{g}-\mathrm{C}_{3} \mathrm{~N}_{4}$ nanosheet $/ \mathrm{Ag}_{3} \mathrm{BiO}_{3}$ on the decomposition of organic matter was investigated, and the activity and satiability of this binary photocatalyst were attributed to effective transfer and separation photogenerated charges from $\mathrm{g}_{-} \mathrm{C}_{3} \mathrm{~N}_{4}$ to $\mathrm{Ag}_{3} \mathrm{BiO}_{3}$ and the presence of semiconductor with a small bang gap [62].

The direct solid-state Z-scheme heterojunction photocatalytic construction system was used in the water splitting and removal of organic pollutants. As previously mentioned, pores $\left(\mathrm{h}^{+}\right)$, superoxide radicals $\left({ }^{\circ} \mathrm{O}^{2-}\right)$ and hydroxyl radicals $\left({ }^{\circ} \mathrm{OH}\right)$ are the main reaction factors in photocatalytic performance. The rate of electron-hole pair regeneration can be inhibited by forming a new system of Z-scheme heterojunction system. Synthetic Z-scheme $\mathrm{V}_{2} \mathrm{O}_{5} / g-\mathrm{C}_{3} \mathrm{~N}_{4}$ can greatly increase photocatalytic activity compared to pure g- $\mathrm{C}_{3} \mathrm{~N}_{4}$ and $\mathrm{V}_{2} \mathrm{O}_{5}$. Hong et al. have shown that $\mathrm{V}_{2} \mathrm{O}_{5}$ amount has a major effect on the photocatalytic activity of $\mathrm{V}_{2} \mathrm{O}_{5} / \mathrm{g}-\mathrm{C}_{3} \mathrm{~N}_{4}$ precursor photocatalysts. If the amount of $\mathrm{V}_{2} \mathrm{O}_{5}$ is more than $1.0 \%$ by weight, the photocatalytic activity decreases [63]. The result shows that direct fabrication of heterojunctions $\mathrm{V}_{2} \mathrm{O}_{5} / \mathrm{g}-\mathrm{C}_{3} \mathrm{~N}_{4}$ with a direct Z-scheme can improve the separation of the photogenized electron-hole pair. This photocatalyst can be used to decompose contaminants such as $\mathrm{RhB}$ (rhodamine B), TC (tetracycline), methylene blue (MB) and methyl orange (MO) under visible light. The photocatalytic decomposition of phenol and methyl orange (MO) in the aqueous solution was investigated with g$\mathrm{C}_{3} \mathrm{~N}_{4} / \mathrm{Ag}_{2} \mathrm{VO}_{2} \mathrm{PO}_{4}$ and found to be approximately 3 to 4 times more active than g- $\mathrm{C}_{3} \mathrm{~N}_{4}$ and $\mathrm{Ag}_{2} \mathrm{VO}_{2} \mathrm{PO}_{4}$ [64]. Also g- $\mathrm{C}_{3} \mathrm{~N}_{4} / \mathrm{Ag}_{2} \mathrm{VO}_{2} \mathrm{PO}_{4}$ is able to break down $30 \%$ of the phenol under 240 minutes disposal to visible light irradiation. Injection of electrons from the $\mathrm{Ag}_{2} \mathrm{VO}_{2} \mathrm{PO}_{4}$ conduction band into the $\mathrm{g}_{-} \mathrm{C}_{3} \mathrm{~N}_{4}$ valence band suppresses the quick recombination procedure and extends the charge carrier life, thus improving the photocatalyst effect. Using the photocurrent graph, it is 
found that the $\mathrm{g}-\mathrm{C}_{3} \mathrm{~N}_{4} / \mathrm{Ag}_{2} \mathrm{VO}_{2} \mathrm{PO}_{4}$ photocurrent density is much higher than that of pure $\mathrm{g}_{-} \mathrm{C}_{3} \mathrm{~N}_{4}$ and $\mathrm{Ag}_{2} \mathrm{VO}_{2} \mathrm{PO}_{4}$. The ratio of this difference in g- $\mathrm{C}_{3} \mathrm{~N}_{4}$ is 8 times and in $\mathrm{Ag}_{2} \mathrm{VO}_{2} \mathrm{PO}_{4}$ is 20 times. The photostability of g- $\mathrm{C}_{3} \mathrm{~N}_{4} / \mathrm{Ag}_{2} \mathrm{VO}_{2} \mathrm{PO}_{4}$ does not decrease after 6 cycles, this confirmed the excellent combination in terms of photodegradation performance. This can be attributed to the direct Z-scheme heterogeneity between ${ }^{-}-\mathrm{C}_{3} \mathrm{~N}_{4}$ and $\mathrm{Ag}_{2} \mathrm{VO}_{2} \mathrm{PO}_{4}$, which efficiently results in charge separation. Recent advances have been made in the field of photocatalytic organic synthesis based on two-dimensional semiconductor with surface defect engineering. [65]. Zhang et al. used $\mathrm{Ag} @ \mathrm{AgVO}_{3}$ nanowires/graphene/protonated $\quad \mathrm{g}^{-} \mathrm{C}_{3} \mathrm{~N}_{4} \quad$ nanosheets $\left(\mathrm{Ag} @ \mathrm{AgVO}_{3} / \mathrm{rGO} / \mathrm{PCN}\right)$ for the photocatalytic degradation of phenol, $\mathrm{MB}$, and MO. This three-compound photocatalyst is efficient for the degradation of organic pollutants under sunlight irradiation because of the intense visible light absorption of 1DAg @ $\mathrm{AgVO}_{3}$ nanowires, electronic conductivity of two-dimensional graphene with outstanding physical and chemical properties [66], wide surfaces and fast transmission, and the separation of fast load interfaces [67]. The large surface area of $\mathrm{Ag} @ \mathrm{AgVO}_{3} / \mathrm{rGO} / \mathrm{PCN}$ heteroconjugates is due to the one-dimensional $\mathrm{Ag} @ \mathrm{AgVO}_{3}$ bridge nanowires as the distance between 2D PCN and GO nanosheets of graphene oxide nanosheets to prevent the accumulation of both nanoplates and the creation of threedimensional porous structures. The 2D nanosheet form of photocatalysts have many substantial superiorities over common threedimensional nanoparticle photocatalysts, containing amended light absorption specifications, shortening of hole and electron transfer routes to the surface of photocatalysts (therefore, undesirable recombination of the electron-hole pair is minimized), and numerous defects of surface, the possibility of modulating the band and facilitating the transfer of charge from the semiconductor to the absorbers [68].

It is reported that the $\mathrm{Z}$-scheme $\mathrm{BiVO}_{4}-\mathrm{Ru} / \mathrm{SrTiO}_{3}: \mathrm{Rh}$ composite photocatalyst is useful for solar water splitting and the photocatalytic activity forcefully depend on the synthesis method [69]. Photocatalytic activity also depends on $\mathrm{pH}$, so that in acidic conditions it is higher than neutral $\mathrm{pH}$ due to weak interaction between $\mathrm{BiVO}_{4}$ and $\mathrm{SrTiO}_{3}: \mathrm{Rh}$ particles. Therefore, the result of heat treatment in the air should be investigated for the physical mixture, as heat treatment can establish a great contact between $\mathrm{Ru} / \mathrm{SrTiO}_{3}: \mathrm{Rh}$ and $\mathrm{BiVO}_{4}$ when both materials are blended together. However, heat treatment has an adverse effect on photocatalytic activity because cocatalytic degradation occurs and the mixture activity of $\mathrm{BiVO}_{4}$ and $\mathrm{Ru} / \mathrm{SrTiO}_{3}: \mathrm{Rh}$ is completely reduced under heat treatment. Also, the result of heat treatment in the air on the Composite-LSR mixture $\left(\mathrm{BiVO}_{4}: \mathrm{Ru} 0.7 \mathrm{wt} \% / \mathrm{SrTiO}_{3}-\mathrm{Rh} 1 \%\right.$ ), which shows the highest activity, has been investigated and the result has shown that its activity also decreases with heat treatment. In the process of water splitting using $\mathrm{BiVO}_{4}-\mathrm{Ru} / \mathrm{SrTiO}_{3}: \mathrm{Rh}$ under sunlight illumination, photocatalytic activity depends on the aqueous solution $\mathrm{pH}$. Neutral $\mathrm{pH}$ conditions can provide the highest and most stable activity. However, the optimum $\mathrm{pH}$ value depends on the ratio of $\mathrm{BiVO}_{4}$ and $\mathrm{Ru} / \mathrm{SrTiO}_{3}: \mathrm{Rh}$ mixture. To maintain a equipoise among the negative and positive effects of $\mathrm{pH}$, an appropriate $\mathrm{pH}$ value of 7 is considered.

Studies by Min et al. have shown that $\mathrm{FeVO}_{4} / \mathrm{TiO}_{2}, \mathrm{BiVO}_{4} / \mathrm{TiO}_{2}$, $\mathrm{InVO}_{4} / \mathrm{TiO}_{2}$, and $\mathrm{Ag}_{3} \mathrm{VO}_{4} / \mathrm{TiO}_{2}$ heterostructure photocatalysts have a marked change in the absorption band compared to the $\mathrm{P} 25\left(\mathrm{TiO}_{2}\right)$ and differed notably, which is attributed to the transfer charge between $\mathrm{TiO}_{2}$ and vanadate. These photocatalysts have a stronger structure in the range of 400-600 nm. Because $\mathrm{TiO}_{2}$ has higher energy levels than $\mathrm{BiVO}_{4}, \mathrm{Ag}_{3} \mathrm{VO}_{4}$, and $\mathrm{FeVO}_{4}$, direct intinction of electrons into the titania conductor band facilitated the transfer to the conduction band $\mathrm{BiVO}_{4}, \mathrm{Ag}_{3} \mathrm{VO}_{4}$, and $\mathrm{FeVO}_{4}$, and expanded the applications of these photocatalytic species. The photocatalytic activity of vanadium $/ \mathrm{TiO}_{2}$ nanostructures using Rh.B decomposition under visible light illumination is remarkably higher than that of $\mathrm{TiO}_{2}$. Moreover, $\mathrm{InVO}_{4} / \mathrm{TiO}_{2}$ heterostructure composite exhibits great performance among other heterostructure composites. In a study by Yan et al., the outcome of $\mathrm{InVO}_{4}$ photocatalytic particle size on its performance was investigated and it was found that $\mathrm{InVO}_{4}$ nanocrystals performs better than that of $\mathrm{InVO}_{4}$ microspheres [70]. Shen et al. also considered a hydrothermal pathway for the synthesis of $\mathrm{RGO}-\mathrm{InVO}_{4}$ nanostructures and proved that proper integration of $\mathrm{RGO}$ and $\mathrm{InVO}_{4}$ provides better photocatalytic performance than $\mathrm{InVO}_{4}$ and $\mathrm{RGO}$ alone. [71]. In this regard, a closed system at relatively high temperatures and internal pressures has been used to minimize defects, which recovers the $\pi$ conjunction graphene bond. The reason for the increase in efficiency of $\mathrm{InVO}_{4}-\mathrm{RGO}$ has been attributed to the increase in surface area and the scattered nature of the RGO as support and catalyst. The entry of $\mathrm{InVO}_{4}$ nanoparticles into the RGO prevents the graphite structure from forming on top of each other. Metal nanoparticles, acting as a spacer, increase the distance between the sheets, thus making both sides of the RGO accessible, which in turn ensures that the specific surface area is high. The photocatalytic effect of $\mathrm{InVO}_{4}$ can also be enhanced by combining $\mathrm{BiVO}_{4}$ and $\mathrm{CNQDs}\left(\mathrm{g}-\mathrm{C}_{3} \mathrm{~N}_{4}\right.$ quantum dots) as these help to effectively separate electron pairs and increase photocatalytic efficiency for water treatment under visible light illumination. Additionally, coating $\mathrm{g}_{-} \mathrm{C}_{3} \mathrm{~N}_{4}$ quantum dots can enhance the performance of visible light attraction, which is moreover useful for nanostructures to be capable to photolysis rhodamine $\mathrm{B}$, so increasing the photocatalytic efficiency of the $\mathrm{BiVO}_{4} / \mathrm{InVO}_{4} / \mathrm{CNQDs}$ nanocomposite [72]. Another important parameter for examining photocatalysts is their stability in multiple cycles. Stability is one of the most important factors in selecting photocatalysts to promote their practical application. The results of the stability test show that the degradation rate of $\mathrm{BiVO}_{4} / \mathrm{InVO}_{4} / \mathrm{CNQDs}$ photocatalysts decreased slightly after 280 minutes of repeated five-step irradiation. The photocatalytic mechanism of the $\mathrm{BiVO}_{4} / \mathrm{InVO}_{4} / \mathrm{CNQDs}$ composite revealed that under visible light illumination, after the incorporation of hydroxyl radical 2-propanol, and hole ammonium oxalate the degradation rate of $\mathrm{Rh} \mathrm{B}$ had low reduction, indicating that holes and $\mathrm{OH}^{-}$groups were involved but not main radical groups. However, the decomposition of Rh B was notably suppressed in the attendance of the 4-benzoquinone ${ }^{\circ} \mathrm{O}^{2-}$ group inhibitor. Thus, the ${ }^{\circ} \mathrm{O}^{2-}$ radical activated species were the main reactive oxygen species for the $\mathrm{BiVO}_{4} / \mathrm{InVO}_{4} / \mathrm{CNQDs}$ photocatalyst in Rh B mixture under sunlight. One of the available metal oxides, $\mathrm{NiO}$ nanostructure [73], has been used as a semiconductor with a stable band gap [74] in photocatalytic processes. The photocatalytic activities of $\mathrm{NiO} / \mathrm{InVO}_{4}$ and single $\mathrm{InVO}_{4}$ were investigated by Lin et al. for the water splitting in Pyrex glass container under visible light illumination [75]. After loading $\mathrm{NiO}$, numerous holes are made on the surface of $\mathrm{InVO}_{4}$ photocatalyst, which facilitated the production of hydrogen gas. For the preparation of $\mathrm{NiO}$ nanoparticles, semi-solid complexes of nickel anthranilic acid with solid state decomposition can be used [76].

Wei et al. have constructed microsphere $\mathrm{n}-\mathrm{BiVO}_{4} / \mathrm{p}-\mathrm{Ag}_{2} \mathrm{~S}$ photocatalyst by depositing p-type $\mathrm{Ag}_{2} \mathrm{~S}$ on n-type $\mathrm{BiVO}_{4}$ (Fig. 3) and have proved 


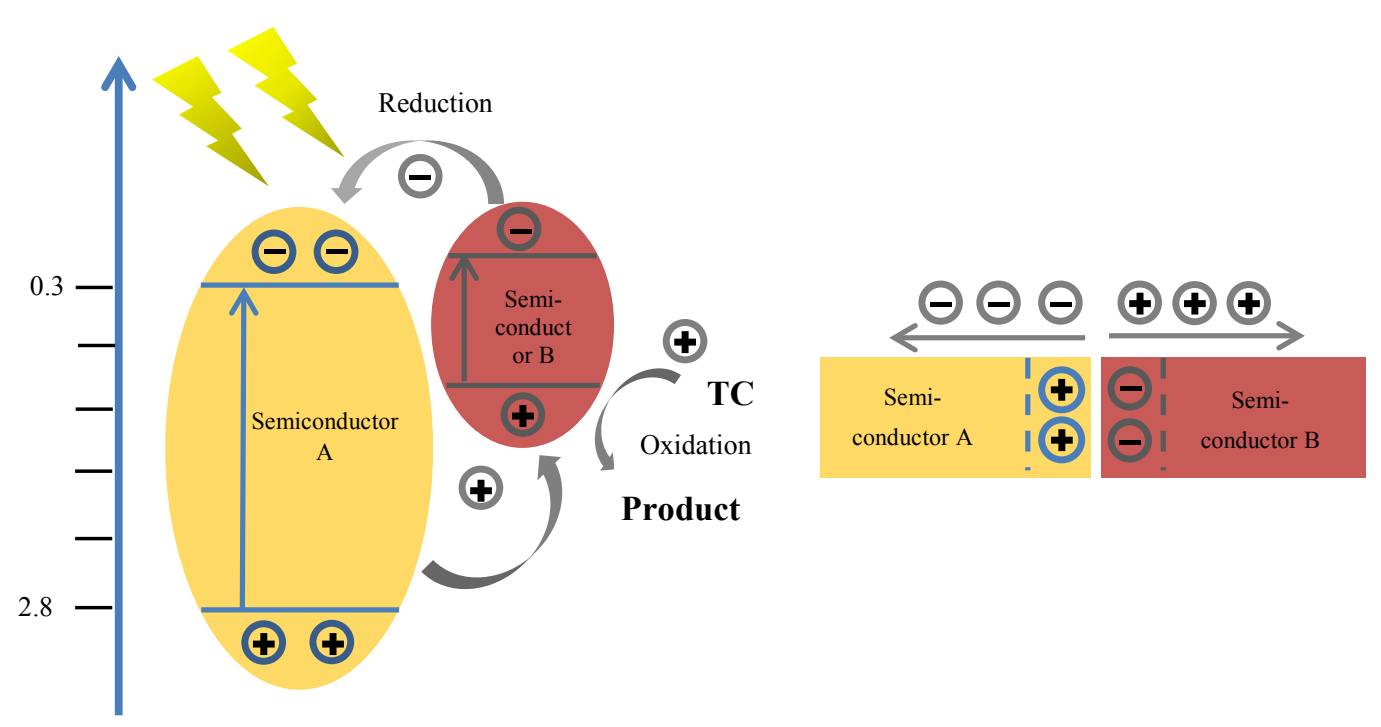

Fig. 3. The photocatalysis enhancement mechanism of p-n heterojunction photocatalyst.

that this three-dimensional photocatalyst performed better than $\mathrm{Ag}_{2} \mathrm{~S}$ and $\mathrm{BiVO}_{4}$ for the decomposition of tetracycline (TC) under visible light illumination [77]. With low levels of $\mathrm{Ag}_{2} \mathrm{~S}$, carrier trapping sites increase, which increases carrier life span, thus improving photocatalytic activity. Conversely, if the $\mathrm{Ag}_{2} \mathrm{~S}$ deposition amount is too high, an overload of $\mathrm{Ag}_{2} \mathrm{~S}$ may block the transfer of electrons produced by the light and thus reduce the exposure of the active site due to the high overlap of the $\mathrm{Ag}_{2} \mathrm{~S}$ particles. TC degradation is a firstorder reaction and has been shown using 0.3-p- n- $-\mathrm{BVO}_{4} / \mathrm{p}-\mathrm{Ag}_{2} \mathrm{~S}$ to be 15 and 5 times faster than $\mathrm{Ag}_{2} \mathrm{~S}$ and $\mathrm{BiVO}_{4}$, respectively. Increasing the separation yield of photogenized charges and increasing the life of the charge carrier leads to increased photocatalytic performance.

Copper oxide is a p-type semiconductor with much higher conduction band energy than conventional semiconductors [78]. In current $\mathrm{Cu}_{2} \mathrm{O} / \mathrm{BiVO}_{4}$ composites, $\mathrm{Cu}_{2} \mathrm{O}$ is a semiconductor with bandwidth of $2.0 \mathrm{eV}$ and has a remarkable ability to absorb sunlight. The heterogeneous nanostructures of the $\mathrm{p}-\mathrm{n}_{2} \mathrm{O} / \mathrm{BiVO}_{4}$ bond, which are synthesized by the growth of $\mathrm{Cu}_{2} \mathrm{O}$ nanoparticles on pre-produced $\mathrm{BiVO}_{4}$ nanostructures by junction a polyol technique with a hydrothermal procedure, are also associated with significantly efficient electron hole separation and excellent photocatalytic activity compared to the individual $\mathrm{BiVO}_{4}$ nanocrystals for the decomposition of $\mathrm{MB}$ and phenol under visible light illumination [79]. The p-n junction shape between n-type $\mathrm{BiVO}_{4}$ and p-type $\mathrm{Cu}_{2} \mathrm{O}$ semiconductors can increase the photocatalytic activity of heterogeneous $\mathrm{Cu}_{2} \mathrm{O} / \mathrm{BiVO}_{4}$ nanostructures. In this combination, increasing the separation of charge by nanoparticles by contacting $\mathrm{Cu}_{2} \mathrm{O}$ with the holes and electrons produced by light, gives enough time to participate in photocatalytic reactions and leads to increase efficiency.

One of the most greatly used materials in the field of photocatalysis is black phosphorus (BP), which has been extensively studied due to its adjustable band gap, high hole mobility and wide optical absorption range [80]. However, because of the low separation efficiency of the charge carriers caused by the photo, pristine black phosphorus can be combined with other materials to show good photocatalytic activity. Inspired by nature, a new photocatalytic system has been developed based on the artificial Z-scheme with a two-dimensional (2D) structure of black phosphorus $(\mathrm{BP}) / \mathrm{BiVO}_{4}$. There is an effective charge separation that oxidizes and reduces water in $\mathrm{BiVO}_{4}$ and $\mathrm{BP}$, respectively. For this purpose, $\mathrm{BP}$ nanoflakes were synthesized via an ultrasonication exfoliation procedure, while $\mathrm{BiVO}_{4}$ nanosheets were prepared via the hydrothermal method. $\mathrm{Zhu}$ et al. were able to achieve the desired rate of $\mathrm{O}_{2}$ and $\mathrm{H}_{2}$ production in $\mathrm{BP} / \mathrm{BiVO}_{4}$ of about 102 and $160 \times 10^{-6} \mathrm{~mol} \mathrm{~g}^{-1} \mathrm{~h}^{-1}$ under $>420 \mathrm{~nm}$ light illumination, without the use of sacrifice or external bias factors [81]. Compared to other systems such as $\mathrm{BP} / \mathrm{Co}_{3} \mathrm{O}_{4}$ and $\mathrm{BiVO} / / \mathrm{Co}_{3} \mathrm{O}_{4}, \mathrm{BP} / \mathrm{BiVO}_{4}$ has been shown to exhibit better photocatalytic activity even without any sacrificial agents. Moreover, as light intensity decreases, both $\mathrm{H}_{2}$ and $\mathrm{O}_{2}$ production are reduced. But the products of $\mathrm{H}_{2}$ and $\mathrm{O}_{2}$ are not linear with photon intensities. The concentrations of electrons and holes for $\mathrm{BiVO}_{4}$ and $\mathrm{BP} / \mathrm{BiVO}_{4}$ are reduced to multi-exponential due to the recombination of the charge in a short time. Charger concentrations for pure BP are also reduced because of the rapid recombination of holes and electrons produced in pure $\mathrm{BP}$ in a short time. $\mathrm{BiVO}_{4}$ and $\mathrm{BP}$ are both fully capable of generating electrons and holes under irradiation visible light more than $400 \mathrm{~nm}$. Electrons trapped in shallow and deep sites have the short lifespan and long lifespan of components, respectively, before recombination between $\mathrm{CB}$ electrons and VB holes. Due to the load transfer path from conduction band of $\mathrm{BiVO}_{4}$ to the adjacent valence band of black phosphorus, the shorter lifetime is for $\mathrm{BP} / \mathrm{BiVO}_{4}$. Table 1 summarizes the photocatalytic results of vanadate-base compounds under different conditions. 
Table 1. Comparison of photoatalytic effects of vanadate.

\begin{tabular}{|c|c|c|c|c|c|c|c|c|c|}
\hline Photocatalyst & $\begin{array}{l}\text { Synthesis } \\
\text { Method }\end{array}$ & $\begin{array}{l}\text { Irradiation } \\
\text { time }\end{array}$ & $\mathbf{p H}$ & Efficiency & $\begin{array}{l}\text { Band } \\
\text { gap }\end{array}$ & Target & $\begin{array}{l}\text { Light } \\
\text { source }\end{array}$ & Notes & Ref. \\
\hline $\mathrm{Pt}-\mathrm{BiVO}_{4}$ & $\begin{array}{l}\text { Facile } \\
\text { microwave- } \\
\text { assisted }\end{array}$ & $60 \mathrm{~min}$ & 3 & $\begin{array}{l}\text { Ciprofloxacin } \\
\text { degradation } \\
\text { ratio of } \\
91.97 \%\end{array}$ & $2.35 \mathrm{eV}$ & $\begin{array}{l}\text { Degradation } \\
\text { of CIP }\end{array}$ & $\begin{array}{l}150 \quad \mathrm{~W} \\
\text { tungsten } \\
\text { halogen } \\
\text { lamp } \\
360-760 \\
\mathrm{~nm}\end{array}$ & $\begin{array}{l}\text { The degradation of CIP was } \\
\text { carried out at } 35{ }^{\circ} \mathrm{C} \text { in a } \\
\text { photochemical container. }\end{array}$ & [48] \\
\hline $\begin{array}{l}\mathrm{BiVO}_{4} / \mathrm{Ag}_{3} \mathrm{PO}_{4} / \mathrm{PANI} \\
-6 \% \quad \text { (polymer } \\
\text { polyaniline) }\end{array}$ & In-situ & $60 \mathrm{~min}$ & & $\begin{array}{l}\text { Degradation } \\
\text { efficiency of } \\
85.92 \%\end{array}$ & $\begin{array}{l}2.4-2.5 \\
\left(\mathrm{BiVO}_{4}\right)\end{array}$ & $\begin{array}{l}\text { Wastewater } \\
\text { treatment }\end{array}$ & $\begin{array}{l}300 \quad W \\
\text { xenon } \\
\text { lamp, } 420 \\
\text { nm cut- } \\
\text { off filter }\end{array}$ & $\begin{array}{l}\text { Prior to reaction, the mixture } \\
\text { should be stirred vigorously } \\
\text { in the dark for } 30 \mathrm{~min} \text { to } \\
\text { achieve the adsorption- } \\
\text { desorption equilibrium. }\end{array}$ & {$[55]$} \\
\hline $\begin{array}{l}\text { Z-scheme } \\
\mathrm{C}_{3} \mathrm{~N}_{4} / \mathrm{BiVO}_{4}\end{array}$ & $\begin{array}{l}\text { Mixed } \\
\text { calcination } \\
\text { procedure }\end{array}$ & $300 \mathrm{~min}$ & 7 & $\begin{array}{l}\text { Degradation } \\
\text { efficiency of } \\
85 \%\end{array}$ & & $\begin{array}{l}\text { Degradation } \\
\text { of } \mathrm{RhB}\end{array}$ & $\begin{array}{l}500 \quad W \\
\text { xenon } \\
\text { lamp, } \\
\lambda>420 \mathrm{~nm}\end{array}$ & $\begin{array}{l}\mathrm{Na}_{2} \mathrm{SO}_{4} \text { was used as the } \\
\text { supporting electrolyte. }\end{array}$ & {$[59]$} \\
\hline $\begin{array}{l}\text { Z-scheme } \\
\mathrm{C}_{3} \mathrm{~N}_{4} / \mathrm{V}_{2} \mathrm{O}_{5} \\
\text { heterojunctions }\end{array}$ & In-situ & $60 \mathrm{~min}$ & & $\begin{array}{l}95.5 \% \\
\text { degradation of } \\
\text { RhB }\end{array}$ & $\begin{array}{l}2.3 \mathrm{eV} \\
\left(\mathrm{V}_{2} \mathrm{O}_{5}\right)\end{array}$ & $\begin{array}{l}\text { Degradation } \\
\text { RhB and TC }\end{array}$ & $\begin{array}{l}250 \quad \mathrm{~W} \\
\text { xenon } \\
\text { lamp, a } \\
420 \mathrm{~nm} \\
\text { cutoff } \\
\text { filter }\end{array}$ & $\begin{array}{l}\text { Metalless } \quad \mathrm{g}^{-} \mathrm{C}_{3} \mathrm{~N}_{4} \text { bulk } \\
\text { powders were prepared by } \\
\text { heat treatment of melamine. }\end{array}$ & [63] \\
\hline $\begin{array}{l}\text { g- } \mathrm{C}_{3} \mathrm{~N}_{4} / \mathrm{Ag}_{2} \mathrm{VO}_{2} \mathrm{PO}_{4} \\
\text { Z-scheme }\end{array}$ & $\begin{array}{l}\text { Hydrothermal } \\
\text { method for } \\
\mathrm{Ag}_{2} \mathrm{VO}_{2} \mathrm{PO}_{4} \text {, g- } \\
\mathrm{C}_{3} \mathrm{~N}_{4} \text { by heating } \\
\text { melamine }\end{array}$ & $120 \mathrm{~min}$ & & $\begin{array}{l}40 \% \\
\text { photodegraded }\end{array}$ & $\begin{array}{l}\sim 2.74 \\
\mathrm{eV} \text { for } \\
\mathrm{g}-\mathrm{C}_{3} \mathrm{~N}_{4}\end{array}$ & $\begin{array}{l}\text { Degradation } \\
\text { of phenol and } \\
\text { MO solution }\end{array}$ & $\begin{array}{l}1000 \quad W \\
\text { halogen } \\
\text { lamp, a } \\
\text { JB } 420 \\
\text { cutoff } \\
\text { filter } \\
\lambda>420 \mathrm{~nm}\end{array}$ & $\begin{array}{l}\text { To prepare } \\
\mathrm{C}_{3} \mathrm{~N}_{4} / \mathrm{Ag}_{2} \mathrm{VO}_{2} \mathrm{PO}_{4} \\
\text { heterojunction photocatalyst, } \\
\text { powders were added into } \\
\text { deionized water, followed by } \\
30 \text { min of ultrasonication. } \\
\text { The mixture was heated in an } \\
\text { oven and dried at } 200{ }^{\circ} \mathrm{C} \text { for } \\
3 \mathrm{~h} \text {. }\end{array}$ & [64] \\
\hline $\begin{array}{l}\mathrm{Ag}: \mathrm{AgVO}_{3} / \mathrm{rGO} / \mathrm{PCN} \\
\text { (protonated } \\
\mathrm{C}_{3} \mathrm{~N}_{4} \text { nanosheets) }\end{array}$ & $\begin{array}{l}\text { Electrostatic } \\
\text { self-assembly }\end{array}$ & $120 \mathrm{~min}$ & & $\begin{array}{l}\sim 98.9 \% \quad \mathrm{MB} \\
\text { degradation }\end{array}$ & & $\begin{array}{l}\text { Degradation } \\
\text { of methylene } \\
\text { blue }(\mathrm{MB})\end{array}$ & & $\begin{array}{l}\text { MO } \sim 86 \% \text { in } 20 \mathrm{~min} \text {, phenol } \\
\sim 81 \% \text { in } 60 \text { min was } \\
\text { decomposed. }\end{array}$ & {$[67]$} \\
\hline $\begin{array}{l}\mathrm{BiVO}_{4}-\mathrm{Ru} / \mathrm{SrTiO}_{3}: \\
\mathrm{Rh} \quad \mathrm{Z} \text {-scheme } \\
\text { composite }\end{array}$ & $\begin{array}{l}\text { Impregnation } \\
\text { procedure, } \\
\text { liquid-solid } \\
\text { state reaction }\end{array}$ & & 7 & $\begin{array}{l}\text { Quantum yield } \\
\text { of } 1.6 \% \text { under } \\
420 \mathrm{~nm}\end{array}$ & & $\begin{array}{l}\text { Water } \\
\text { splitting }\end{array}$ & $\begin{array}{l}300 \mathrm{~W} \text { Xe } \\
\text { lamp, a } \\
\text { cut-off } \\
\text { filter and } \\
\text { cold } \\
\text { mirror }\end{array}$ & $\begin{array}{l}\text { Photocatalytic process was } \\
\text { mainly performed in a closed } \\
\text { gas circulation system and an } \\
\text { irradiation cell with a Pyrex } \\
\text { window. }\end{array}$ & [69] \\
\hline $\begin{array}{l}\text { Reduced graphene } \\
\text { oxide (RGO)-- } \mathrm{InVO}_{4}\end{array}$ & $\begin{array}{l}\text { Hydrothermal } \\
\text { method for } \\
\mathrm{InVO}_{4}, \\
\text { sonication for } \\
\text { RGO }\end{array}$ & $120 \mathrm{~min}$ & 8 & & $\begin{array}{l}2.0 \mathrm{eV} \\
\text { for } \\
\mathrm{InVO}_{4}\end{array}$ & $\begin{array}{l}\text { Removal of } \\
\text { methyl } \\
\text { orange and } \\
\mathrm{Cr}(\mathrm{VI})\end{array}$ & Xe lamp & $\begin{array}{l}\text { The whole process can be } \\
\text { carried out under mild } \\
\text { conditions. }\end{array}$ & [71] \\
\hline $\begin{array}{l}\mathrm{InVO}_{4} / \mathrm{BiVO}_{4} / \\
\mathrm{CNQDs} \quad\left(\mathrm{g}-\mathrm{C}_{3} \mathrm{~N}_{4}\right. \\
\text { quantum dots })\end{array}$ & & $40 \mathrm{~min}$ & 3 & $\begin{array}{l}100 \% \text { of the } \\
\text { Rh B was } \\
\text { degraded. }\end{array}$ & $\begin{array}{l}2.70 \mathrm{eV} \\
\text { for } \\
\text { CNQDs }\end{array}$ & $\begin{array}{l}\text { Degradation } \\
\text { of rhodamine } \\
\mathrm{B}(\mathrm{RhB})\end{array}$ & $\begin{array}{l}300 \mathrm{~W} \mathrm{Xe} \\
\text { lamp, } \\
\lambda>420 \mathrm{~nm}\end{array}$ & & {$[72]$} \\
\hline $\mathrm{NiO} / \mathrm{InVO}_{4}$ & $\begin{array}{l}\text { Solid-state } \\
\text { reaction method }\end{array}$ & $120 \mathrm{~min}$ & & $\begin{array}{l}\text { The apparent } \\
\text { quantum yield } \\
\text { was } 56 \%\end{array}$ & $\begin{array}{l}3.6-4.0 \\
\mathrm{eV} \text { for } \\
\mathrm{NiO}\end{array}$ & $\begin{array}{l}\text { Water } \\
\text { splitting }\end{array}$ & $\begin{array}{l}500 \quad W \\
\text { halogen } \\
\text { lamp }\end{array}$ & $\begin{array}{l}\text { Pyrex glass reactor equipped } \\
\text { with cooling water }\end{array}$ & {$[75]$} \\
\hline $\begin{array}{l}\mathrm{n}-\mathrm{BiVO}_{4} / \mathrm{p}-\mathrm{Ag}_{2} \mathrm{~S}, \mathrm{n}- \\
\mathrm{p} \text { heterojunction }\end{array}$ & Precipitation & & & $\begin{array}{l}\text { The } \\
\text { degradation } \\
\text { efficiency of } \\
0.3-\mathrm{p}-\mathrm{Ag}_{2} \mathrm{~S} / \mathrm{n} \text { - } \\
\mathrm{BiVO}_{4} \text { can be } \\
\text { achieved } 90 \% \text {. }\end{array}$ & $\begin{array}{l}2.3 \mathrm{eV} \\
\text { for } 0.3- \\
\mathrm{p}- \\
\mathrm{Ag}_{2} \mathrm{~S} / \mathrm{n}- \\
\mathrm{BiVO}_{4}\end{array}$ & $\begin{array}{l}\text { Degradation } \\
\text { of } \\
\text { tetracycline }\end{array}$ & $\begin{array}{l}500 \mathrm{~W} \text { Xe } \\
\text { lamp, a } \\
\text { cut-off } \\
\text { filter (420 } \\
\mathrm{nm})\end{array}$ & $\begin{array}{l}\text { The photocatalyst should be } \\
\text { dispersed in } 50 \mathrm{ml} \text { of } \\
\text { tetracycline }(20 \mathrm{mg} / \mathrm{L}) \text {, } \\
\text { stirred for } 1 \text { hour in the dark } \\
\text { to achieve equilibrium of } \\
\text { absorption and desorption. }\end{array}$ & {$[77]$} \\
\hline
\end{tabular}


Table 1. Continued.

\begin{tabular}{|c|c|c|c|c|c|c|c|c|c|}
\hline Photocatalyst & $\begin{array}{l}\text { Synthesis } \\
\text { Method }\end{array}$ & $\begin{array}{l}\text { Irradiation } \\
\text { time }\end{array}$ & pH & Efficiency & $\begin{array}{l}\text { Band } \\
\text { gap }\end{array}$ & Target & $\begin{array}{l}\text { Light } \\
\text { source }\end{array}$ & Notes & Ref. \\
\hline $\begin{array}{l}\mathrm{p}-\mathrm{n} \quad \text { junction } \\
\mathrm{Cu}_{2} \mathrm{O} / \mathrm{BiVO}_{4}\end{array}$ & $\begin{array}{l}\text { Hydrothermal } \\
\text { method }\end{array}$ & $240 \mathrm{~min}$ & 7 & $\begin{array}{l}97.3 \% \text { of } \mathrm{MB} \\
\text { was degraded }\end{array}$ & $\begin{array}{l}2.0 \mathrm{eV} \\
\text { for } \\
\mathrm{Cu}_{2} \mathrm{O}\end{array}$ & $\begin{array}{l}\text { Degradation } \\
\text { of methylene } \\
\text { blue (MB) } \\
\text { and phenol }\end{array}$ & $\begin{array}{l}\text { 300-W Xe } \\
\text { lamp } \\
\text { coupled } \\
\text { with a UV } \\
\text { cut off } \\
\text { filter } \\
(>420 \\
\mathrm{nm})\end{array}$ & $\begin{array}{l}\mathrm{Cu}_{2} \mathrm{O} \text { nanoparticles } \\
\text { grown on the } \\
\text { nanocrystals by a polyol } \\
\text { method. }\end{array}$ & [79] \\
\hline $\begin{array}{l}\text { Heterostructure of } \\
\text { black phosphorus } \\
(\mathrm{BP}) / \mathrm{BiVO}_{4}(2 \mathrm{D})\end{array}$ & $\begin{array}{l}\text { Ultrasonication } \\
\text { exfoliation } \\
\text { method for BP, } \\
\text { hydrothermal } \\
\text { method for } \\
\text { BiVO }_{4} \\
\text { nanosheets }\end{array}$ & $180 \mathrm{~min}$ & & $\begin{array}{l}\text { The apparent } \\
\text { quantum } \\
\text { efficiency } \\
\text { (AQE) of } \mathrm{H}_{2} \\
\text { production is } \\
\text { around } 0.89 \% \text {. }\end{array}$ & & $\begin{array}{l}\text { Oxidation of } \\
\text { water }\end{array}$ & $\begin{array}{l}>420 \mathrm{~nm} \\
\text { light } \\
\text { irradiation }\end{array}$ & & [81] \\
\hline $\begin{array}{l}\mathrm{V}_{2} \mathrm{O}_{5} \\
\text { nanorods/graphene } \\
\text { oxide }(\mathrm{GO})\end{array}$ & $\begin{array}{l}\text { Sonochemical } \\
\text { process }\end{array}$ & $90 \mathrm{~min}$ & & $\begin{array}{l}98 \% \\
\text { degradation of } \\
\text { Victoria Blue } \\
\text { dye }\end{array}$ & & $\begin{array}{l}\text { Degradation } \\
\text { of } \quad \mathrm{VB} \\
\text { (Victoria } \\
\text { Blue dye) }\end{array}$ & & & {$[82]$} \\
\hline $\begin{array}{l}\mathrm{InVO}_{4} / \mathrm{TiO}_{2} \\
\text { heterostructure }\end{array}$ & Ion impregnate & $30 \mathrm{~min}$ & 7 & & $\begin{array}{l}2.1 \mathrm{eV} \\
\text { for } \\
\mathrm{InVO}_{4}\end{array}$ & $\begin{array}{l}\text { Rh.B and } \\
\text { benzoic acid } \\
\text { (BA) } \\
\text { degradation }\end{array}$ & $\begin{array}{l}\text { LED } \\
\text { lamp, } 8 \mathrm{~W}\end{array}$ & & {$[83]$} \\
\hline $\begin{array}{l}\mathrm{FeVO}_{4} / \mathrm{TiO}_{2} \\
\text { heterostructure }\end{array}$ & & $30 \mathrm{~min}$ & 1 & & & & $\begin{array}{l}\text { LED } \\
\text { lamp, } 8 \mathrm{~W}\end{array}$ & $\begin{array}{l}\text { There is a significant } \\
\text { absorption of } 540 \text { to } 800 \mathrm{~nm} \\
\text { for the } \mathrm{FeVO}_{4} \text { sample. }\end{array}$ & {$[83]$} \\
\hline $\begin{array}{l}\mathrm{Ag}_{3} \mathrm{VO}_{4} / \mathrm{TiO}_{2} \\
\text { heterostructure }\end{array}$ & & $30 \mathrm{~min}$ & 7 & & & & $\begin{array}{l}\text { LED } \\
\text { lamp, } 8 \mathrm{~W}\end{array}$ & $\begin{array}{l}\text { The absorption edge of the } \\
\mathrm{Ag}_{3} \mathrm{VO}_{4} \text { is about } 600 \mathrm{~nm} \text {. }\end{array}$ & {$[83]$} \\
\hline $\begin{array}{l}\mathrm{BiVO}_{4} / \mathrm{TiO}_{2} \\
\text { heterojunction }\end{array}$ & $\begin{array}{l}\text { Hydrothermal } \\
\text { method }\end{array}$ & $60 \mathrm{~min}$ & & & & $\begin{array}{l}\text { RhB } \\
\text { degradation }\end{array}$ & $\begin{array}{l}\text { LED lamp } \\
(4 \mathrm{~W})\end{array}$ & & {$[84]$} \\
\hline $\begin{array}{l}\mathrm{BP} / \mathrm{BiVO}_{4} / \mathrm{Co}_{3} \mathrm{O}_{4} \\
\text { (agent: } \mathrm{AgNO}_{4} \text { ) }\end{array}$ & $\begin{array}{l}\text { Hydrothermal } \\
\text { method }\end{array}$ & $180 \mathrm{~min}$ & & $\begin{array}{l}\mathrm{AQE} \text { of } \mathrm{H}_{2} \\
\text { production is } \\
\text { around } 4.45 \% \text {. }\end{array}$ & & $\begin{array}{l}\text { Water } \\
\text { splitting }\end{array}$ & $\begin{array}{l}\text { Visible } \\
\text { light } \\
(>420 \\
\mathrm{nm})\end{array}$ & & {$[85]$} \\
\hline $\begin{array}{l}\mathrm{BP} / \mathrm{BiVO} \mathrm{V}_{4} / \mathrm{Co}_{3} \mathrm{O}_{4} \\
\text { (agent: } \\
\text { ethylenediaminetetraa } \\
\text { cetic acid: EDTA) }\end{array}$ & $\begin{array}{l}\text { Hydrothermal } \\
\text { method }\end{array}$ & $180 \mathrm{~min}$ & & $\begin{array}{l}\text { AQE of } \mathrm{H}_{2} \\
\text { production is } \\
\text { around } 6.5 \% \text {. }\end{array}$ & & $\begin{array}{l}\text { Water } \\
\text { splitting }\end{array}$ & $\begin{array}{l}\text { Visible } \\
\text { light } \\
(>420 \\
\mathrm{nm})\end{array}$ & & {$[85]$} \\
\hline $\begin{array}{l}\text { Nanoporous } \\
\mathrm{BiVO}_{4} / \mathrm{Bi}_{2} \mathrm{~S}_{3} \\
\text { nanosheets }\end{array}$ & $\begin{array}{l}\text { Hydrothermal } \\
\text { method }\end{array}$ & $40 \mathrm{~min}$ & 1.7 & & $\begin{array}{l}<2.03 \\
\mathrm{eV}\end{array}$ & $\begin{array}{l}\text { Water } \\
\text { splitting }\end{array}$ & $\begin{array}{l}300 \mathrm{~W} \text { Xe } \\
\text { lamp and } \\
\text { AM } 1.5\end{array}$ & $\begin{array}{lr}\begin{array}{l}\text { Loading } \mathrm{FeOOH} \\
\text { enhance }\end{array} & \begin{array}{r}\text { could } \\
\text { the }\end{array} \\
\text { photoelectrochemical } & \text { water } \\
\text { splitting ability. } & \end{array}$ & {$[86]$} \\
\hline $\mathrm{BiVO}_{4} / \mathrm{ZnFe}_{2} \mathrm{O}_{4}$ & $\begin{array}{l}\text { Multiple } \\
\text { strategy }\end{array}$ & $40 \mathrm{~min}$ & 13 & & $\sim 2.0 \mathrm{eV}$ & $\begin{array}{l}\text { Water } \\
\text { splitting }\end{array}$ & & $\begin{array}{l}\text { When } \mathrm{Co}^{2+} \text { was added, the } \\
\text { resulting much more stable } \\
\text { photocurrent }\end{array}$ & {$[87]$} \\
\hline $\mathrm{Mo}: \mathrm{BiVO}_{4} / \mathrm{Au}$ & $\begin{array}{l}\text { Multiple } \\
\text { strategy }\end{array}$ & & 7 & $\begin{array}{l}\text { Incident } \\
\text { photon-to- } \\
\text { electron } \\
\text { conversion } \\
\text { efficiency } \\
\text { (IPCE) } 41 \%\end{array}$ & $1.23 \mathrm{eV}$ & $\begin{array}{l}\text { Hydrogen } \\
\text { production }\end{array}$ & 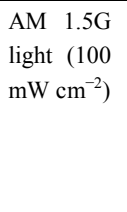 & $\begin{array}{l}\text { By adding a semiconductor } \\
\text { underlayer, the designed } \\
\text { structure overcomes the } \\
\text { reflection losses of light. }\end{array}$ & {$[88]$} \\
\hline $\begin{array}{l}\mathrm{WO}_{3} / \mathrm{BiVO}_{4}, \quad \mathrm{CoPi} \\
\text { core-shell } \\
\text { nanostructured }\end{array}$ & $\begin{array}{l}\text { Glancing angle } \\
\text { deposition } \\
\text { (GLAD) } \\
\text { electrochemical } \\
\text { deposition }\end{array}$ & $180 \mathrm{~min}$ & 7 & $\begin{array}{l}\text { Hydrogen } \\
\text { generation } \\
\text { efficiency of } \\
8.1 \%\end{array}$ & & $\begin{array}{l}\text { Water } \\
\text { splitting }\end{array}$ & Sunlight & Cell temperature of $50^{\circ} \mathrm{C}$ & [89] \\
\hline
\end{tabular}


Table 1. Continued.

\begin{tabular}{|c|c|c|c|c|c|c|c|c|c|}
\hline Photocatalyst & $\begin{array}{l}\text { Synthesis } \\
\text { Method }\end{array}$ & $\begin{array}{l}\text { Irradiation } \\
\text { time }\end{array}$ & pH & Efficiency & $\begin{array}{l}\text { Band } \\
\text { gap }\end{array}$ & Target & $\begin{array}{l}\text { Light } \\
\text { source }\end{array}$ & Notes & Ref. \\
\hline $\begin{array}{l}\text { W/Fe-co-doped } \\
\text { nanoparticles } \mathrm{BiVO}_{4} \\
\text { loaded with } \mathrm{MOF} \\
\text { MIL-100 }\end{array}$ & $\begin{array}{l}\mathrm{BiVO}_{4} \text { by drop- } \\
\text { casting MIL- } \\
100(\mathrm{Fe}) \text { by } \\
\text { hydrothermal } \\
\text { method }\end{array}$ & & 7 & IPCE of $52.6 \%$ & & $\begin{array}{l}\text { Water } \\
\text { splitting }\end{array}$ & $\begin{array}{ll}300 & \text { W } \\
\text { xenon } & \\
\text { lamp } & \end{array}$ & Ambient conditions apply & {$[90]$} \\
\hline $\mathrm{Pt} / \mathrm{MnO}_{\mathrm{x}} / \mathrm{BiVO}_{4}$ & $\begin{array}{l}\text { Impregnation } \\
\text { method }\end{array}$ & $60 \mathrm{~min}$ & & & & $\begin{array}{l}\text { Degradation } \\
\text { of MO and } \\
\text { RhB }\end{array}$ & $\begin{array}{l}300 \mathrm{~W} X \mathrm{Xe} \\
\text { lamp } \\
(\lambda>420 \\
\mathrm{nm})\end{array}$ & $\mathrm{IO}_{3}^{-}$as an electron acceptor & {$[91]$} \\
\hline $\mathrm{Pt} / \mathrm{Co}_{3} \mathrm{O}_{4} / \mathrm{BiVO}_{4}$ & $\begin{array}{l}\text { Photo- } \\
\text { deposition } \\
\text { method }\end{array}$ & $60 \mathrm{~min}$ & & $\begin{array}{l}160.3 \mu \mathrm{mol} \mathrm{h} \mathrm{h}^{-1} \\
\text { of } \mathrm{O}_{2} \text { evolution }\end{array}$ & & $\begin{array}{l}\text { Water } \\
\text { oxidation }\end{array}$ & $\begin{array}{l}300 \mathrm{~W} X \mathrm{Xe} \\
\text { lamp } \\
(\lambda>420 \\
\mathrm{nm})\end{array}$ & & {$[91]$} \\
\hline $\mathrm{CdS} / \mathrm{Bi}_{4} \mathrm{~V}_{2} \mathrm{O}_{11}$ & $\begin{array}{l}\text { Facile in-situ } \\
\text { growth method }\end{array}$ & $120 \mathrm{~min}$ & 7.5 & $77 \%$ activity & $2.21 \mathrm{eV}$ & $\begin{array}{l}\text { Pollutant } \\
\text { degradation }\end{array}$ & $\begin{array}{l}250 \quad W, \\
\text { with a } 420 \\
\text { nm cutoff } \\
\text { filter }\end{array}$ & $\begin{array}{l}\mathrm{Bi}_{4} \mathrm{~V}_{2} \mathrm{O}_{11} \quad \text { prepared by } \\
\text { solvothermal method. }\end{array}$ & {$[92]$} \\
\hline $\mathrm{Mn}_{2} \mathrm{~V}_{2} \mathrm{O}_{7}$ & $\begin{array}{l}\text { Hydrothermal } \\
\text { process }\end{array}$ & $240 \mathrm{~min}$ & 7 & $\begin{array}{l}90.6 \% \\
\text { degradation }\end{array}$ & $2.79 \mathrm{eV}$ & $\begin{array}{l}\text { Degradation } \\
\text { of methylene } \\
\text { blue }\end{array}$ & $\begin{array}{l}100 \\
\mathrm{~mW} / \mathrm{ml} \text { of } \\
\text { solar } \\
\text { power }\end{array}$ & $\begin{array}{l}\text { Polymer polyvinyl } \\
\text { pyrrolidone (PVP) as the } \\
\text { surfactant and adjusting the } \\
\text { pH value }\end{array}$ & [93] \\
\hline AgBr-Ag-BiVO4 & $\begin{array}{l}\text { Hydrothermal } \\
\text { procedure }\end{array}$ & $180 \mathrm{~min}$ & & & & $\begin{array}{l}\text { Bacterium } \\
\text { inactivation } \\
\text { and organic } \\
\text { pollution } \\
\text { treatment }\end{array}$ & $\begin{array}{l}300 \mathrm{~W} \text { Xe } \\
\text { lamp, a } \\
420 \quad \mathrm{~nm} \\
\text { cutoff } \\
\text { filter }\end{array}$ & $\begin{array}{l}\text { The mass percentage of } \mathrm{Ag} \\
\text { in the total } \mathrm{Ag} \text { and } \mathrm{BiVO}_{4} \text { is } \\
3 \text { wt } \% \text {. }\end{array}$ & {$[94]$} \\
\hline $\begin{array}{l}\text { BVO/BFO (bismuth } \\
\text { vanadate/bismuth } \\
\text { ferrite) }\end{array}$ & $\begin{array}{l}\text { Multiple } \\
\text { strategy }\end{array}$ & $90 \mathrm{~min}$ & 9.5 & $\begin{array}{l}99 \% \text { of } \mathrm{TC} \\
\text { degradation }\end{array}$ & $\begin{array}{l}1.92 \mathrm{eV} \\
\text { for } \mathrm{BFO}\end{array}$ & $\begin{array}{l}\text { TC } \\
\text { degradation }\end{array}$ & $\begin{array}{l}250 \mathrm{~W} X \mathrm{Xe} \\
\text { lamp } \\
((\text { Oriel }), \mathrm{a} \\
420 \mathrm{~nm} \\
\text { cutoff } \\
\text { filter }\end{array}$ & $\begin{array}{l}\text { Process efficiency enhanced } \\
\text { with increasing solution } \mathrm{pH} \text {. }\end{array}$ & {$[95]$} \\
\hline $\mathrm{Ag}_{2} \mathrm{Sr}\left(\mathrm{VO}_{3}\right)_{4}$ & $\begin{array}{l}\text { Solid state } \\
\text { method }\end{array}$ & $180 \mathrm{~min}$ & & $\begin{array}{l}\mathrm{O}_{2} \text {-evolution } \\
\text { rates of } 8 \\
\mu \mathrm{mol} \cdot \mathrm{h}^{-1}\end{array}$ & $2.4 \mathrm{eV}$ & $\begin{array}{l}\text { Water } \\
\text { oxidation }\end{array}$ & $\begin{array}{l}\lambda>400 \\
\mathrm{~nm}, \quad 300 \\
\mathrm{~W}, \mathrm{Xe} \text { arc } \\
\text { lamp, L42 } \\
\text { cut-off } \\
\text { filter) }\end{array}$ & & {$[96]$} \\
\hline $\mathrm{Sr}\left(\mathrm{VO}_{3}\right)_{2}$ & $\begin{array}{l}\text { Solid state } \\
\text { method }\end{array}$ & $180 \mathrm{~min}$ & & $\begin{array}{l}\mathrm{O}_{2} \text {-evolution } \\
\text { rates of } 12 \\
\mu \text { mol.h-1 }\end{array}$ & $2.7 \mathrm{eV}$ & $\begin{array}{l}\text { Water } \\
\text { oxidation }\end{array}$ & $\begin{array}{l}\lambda>400 \\
\mathrm{~nm}, \quad 300 \\
\mathrm{~W}, \mathrm{Xe} \text { arc } \\
\text { lamp, L42 } \\
\text { cut-off } \\
\text { filter }\end{array}$ & & {$[96]$} \\
\hline
\end{tabular}

\section{Applications}

\subsection{Water splitting}

Water splitting to produce hydrogen and oxygen on a photocatalyst under visible light illumination is a hopeful method to produce clean, large-scale hydrogen. Photocatalysis has proven to be the latest technology that can aid in providing solution to energy storage. A potential solution to compensate for the lack of energy is to use solar energy as an endless primary source of energy combined with semiconductor photocatalytic systems. Visible light makes up the bulk of the solar spectrum, so its use can revolutionize the development of photocatalyst applications [97, 98]. One of the most important fuels is hydrogen, which is a promising and renewable chemical fuel due to its high energy density and environmentally friendly [99]. Clean generation of $\mathrm{H}_{2}$ by water splitting using a semiconductor photocatalyst and solar energy, without relying on fossil reserves, is a new technology [60] which is a target pursued by chemists over the past decade. Half of the solar energy at the earth surface is in the visible region $(400<\lambda<800 \mathrm{~nm})$, so the efficient use of visible light is essential to achieve large-scale practical $\mathrm{H}_{2}$ production by photocatalytic water splitting [100]. The advantage of photocatalytic water splitting is that no sacrificial reagent is required to produce hydrogen and oxygen 
[101]. This process is a competitive low-cost technology for large-scale use compared to traditional industrial hydrogen production, including natural gas or methane steam reforming. Achieving a stable, low-cost, non-toxic photocatalyst with the desired solar-hydrogen conversion efficiency is critical to achieving widespread use of this sustainable technology. The overall $\mathrm{H}_{2} \mathrm{O}$ splitting into $\mathrm{H}_{2}$ and $\mathrm{O}_{2}$ is an endothermic reaction that requires $1.23 \mathrm{~V}$ energy [102]. One of the important parameters of this process is the $\mathrm{H}_{2}$ production rate, which is affected by various factors. For efficient conversion of solar energy by a semiconductor-based photocatalyst, the photocatalyst must have a suitable band gap that will not only efficiently absorb light but also a suitable conduction band (CB) and valence band (VB) levels for watersplitting redox reactions [103]. Furthermore, a desirable photocatalyst must be highly effective at isolating and transmitting light-generated charges [104]. Unfortunately, it suffers from recombination photogenerated holes and electrons, which reduces the efficiency of the solar to hydrogen (STH) [105]. The photocatalytic hydrogen production of a ternary composite is significantly improved compared to a single composite. The increase in activity depends mainly on the Schottky effect and the heterogeneous Z-scheme photosynthesis system, in which the effective charge separation is $\mathrm{WO}_{3}$ as a hole collector and $\mathrm{Au}$ as an electron collector. Also, the effect of Surface Plasmon Resonance (SPR) in Au further increases charge separation and visible light absorption. The high decomposition efficiency of $\mathrm{H}_{2} \mathrm{O}$ in the synthetic structure depends on the direct electronic structure of the Z-scheme of ternary photocatalyst and the spatial oxidation units separated from the Z-scheme, which greatly increases the lifespan of the electrons produced by the light and the holes, and prevents the reversibility of the reaction [106]. The constructed direct Z-scheme photocatalysts, which imitate nature's photosynthetic process, have many advantages, such as enhanced light absorption, spatially isolated reductive and oxidative active sites, and well-preserved intense redox capability, which contribute to photocatalytic efficiency [107]. Some parameters such as catalyst dose, $\mathrm{pH}$ values, water source and symbiotic ions affect the photocatalytic performance. Achieving 30\% in terms of quantum performance at $600 \mathrm{~nm}$ for water splits into $\mathrm{H}_{2}$ and $\mathrm{O}_{2}$ has not yet been achieved because a limited number of photocatalysts have been used for water splitting. The $\mathrm{Rh}-\mathrm{BiVO}_{4}$ photocatalyst has responded to split water to about $500 \mathrm{~nm}$. However, to achieve higher quantum performance, we need to work on producing new and superior photocatalyst materials for clean energy production. There are also beneficial opinions for the construction of other new types of metal hydroxide photocatalysts that act by combining anion replacement and cation doping in the visible region [108].

\section{2. $\mathrm{CO}_{2}$ reduction}

The photocatalytic conversion technology of $\mathrm{CO}_{2}$ to carbonaceous chemicals [109] can be used to prepare feedstock for many processes, which is a promising solution to reduce greenhouse gases and storing energy [110]. Understanding the reaction mechanism of $\mathrm{CO}_{2}$ and especially the active site of the photocatalyst can help develop the application of photocatalysts [111]. Because $\mathrm{CO}_{2}$ is an inert gas, it has the tendency to reduce multi-electrons reaction in photocatalysis and determines the high complexity of the reaction for study. Research has shown that increasing photocatalyst activity helps increase $\mathrm{CO}_{2}$ uptake capacity, better absorption of visible-light, and charge transfer from covalent triazine-based framework (CTF) to $\mathrm{CO}_{2}$ molecules [112].
To make effective use of visible light and overcome large-scale defects in metal oxides, several visible light-reactive catalysts have emerged, such as $\mathrm{CsPbr}_{3} \mathrm{QD} / \mathrm{GO}$ [113], doped $\mathrm{NaTaO}_{3}$ [114], Fe-doped $\mathrm{ZnO}$ [115] and BiOBr-GO [116]. Studies have shown that monomeric photocatalysts always lose their photocatalytic activity under the influence of inherent defects such as structural defects, photo corrosion, and rapid recombination of charge carriers produced by light. There are some ways to improve the photocatalytic activity of monomers that can be useful for the industrialization of photocatalysts [117]. For this purpose, conventional methods such as heterogeneous fabrication with other metals, combination with semiconductors, molecular and elemental doping and preparation of nanocomposite have been used so far [118].

\subsection{Air and water purification}

To remove contamination, industrial plants must eliminate synthetic organic dyes from wastewater before its discharging into natural water sources. The photodecomposition of pollutants in air and water is an exciting research interest in photocatalysis [119]. In the field of gas phase photocatalysis, four main uses can be proposed: indoor air, outdoor air, processing gases and soluble pollutants [120]. Each of these applications has special characteristics that can affect the type of optical reactor and the composition of the photocatalyst used compared to other treatments [121]. Photocatalytic conversion of organic compounds such as benzene in polluted ambient air in the presence of $\mathrm{TiO}_{2}$ has been considered [122]. In photocatalytic reactions, several factors such as organic class, water, catalyst type, radiation and oxygen are involved, which complicate the process. Thus, the operational parameters related to each of these factors clearly affect the efficiency of the photocatalytic process. Fig. 4 depicts the mechanism for wastewater treatment.

Several studies have been reported in the use of heterogeneous photocatalysis in the decomposition/elimination of contaminants in the aqueous solution, which includes contaminants such as dyes [123-125], herbicides/pesticides, aromatic compounds, phenols [126] and pharmaceutical effluents [126]. Ciprofloxacin (CIP) and levofloxacin are widespread antibiotics used in the treatment of various infections and has been detected in the aquatic environment recently [127]. Its presence in the environment can simulate bacterial resistance and is a risk to the environment, so it should be eliminated from the water. One of the possible ways for antibiotic treatment is to degrade it in a photocatalytic process [128]. The advantages of removing the residual dye in wastewater by photocatalytic decomposition include as mild photocatalytic conditions, less need for chemical reagents and decomposition of artificial organic dyes into small non-toxic molecules [129]. $\mathrm{TiO}_{2}$-coated nanoparticles absorb natural sunlight at $980 \mathrm{~nm}$ and convert it to ultraviolet and blue light, which is suitable for photocatalytic activation [130]. In this regard, organic dyes such as methylene blue (MB), methyl orange (MO) and rhodamine can be degraded. Photocatalyst must possess high absorption properties and photocatalytic activity before it can be suitable in the removal of recalcitrant organic pollutants in water. Adsorption properties play an important role in the decomposition of methylene blue due to the interaction between methylene blue and photocatalyst molecules [131] Semiconductors such as $\mathrm{Fe}_{2} \mathrm{O}_{3}, \mathrm{WO}_{3}, \mathrm{ZnO}$ and, $\mathrm{TiO}_{2}$ have band gap in the range of 2.2-3.2 eV show unsatisfactory photocatalytic properties due to high band gap energy and restrict their practical application. 


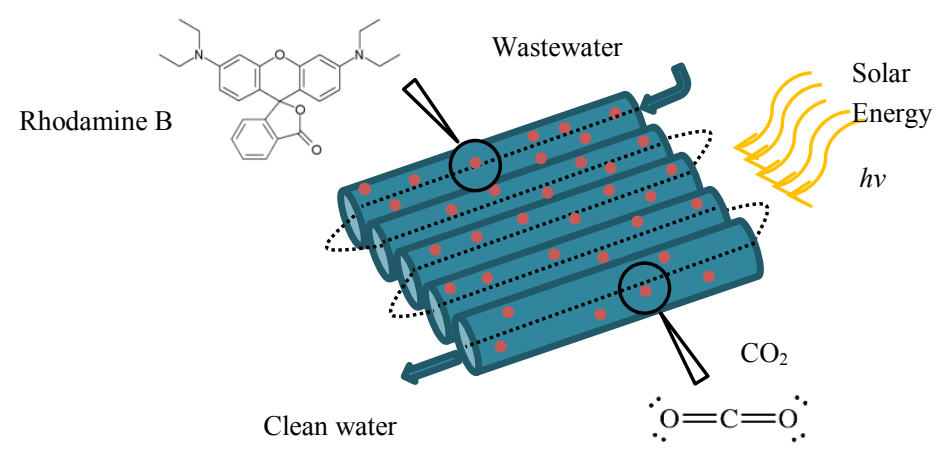

Fig. 4. The mechanism of wastewater treatment.

Incorporating metal ions into their lattice will assist in without negative electron transfer makes them more sensitive to a wide range of solar spectra. By changing the structure of the band gap, the removal of contaminants can be increased. The dye contents can be degraded into a degradable product by binary metal oxide photocatalysts prepared by different procedure. The ternary composite is highly efficient against the photocatalytic oxidation of rhodamine B and methylene blue. For photocatalytic oxidation of rhodamine $\mathrm{B}$ and methylene blue, the ternary composite has a high efficiency [132]. Wide band gaps are present in most photocatalysts and cause them to be active only in the UV region. The solar spectrum contains only about $4 \%$ of ultraviolet illumination. Semiconductors with white color and wide band gaps need to be modified because they do not absorb in the visible range of the spectrum. Photocatalysts can be modified by using methods such as surface modification, composite or pair materials, metallic and nonmetallic doping, and metal complexes to perform better performance [133].

The photocatalytic reaction occurs at the photocatalyst surface and the acid-base properties of the reaction medium have a significant effect on the process efficiency [134]. The $\mathrm{pH}$ variation of the environment causes the surface charge of the photocatalyst to be distributed, given that it will have a positive or negative charge level in relation to the reference value for each substance. Therefore, the efficiency of catalytic activity arises from the amphoteric behavior of materials and its effect on the absorption of organic matter on the substrate. The reaction rate of the photocatalytic process is a function of the photocatalyst mass unit if reach to a certain level, after that, the mass of photocatalyst doesn't affect the reaction rate. In these reactions, it has been proven that the reaction rate increases with increasing organic bed concentration according to the law of velocity.

The active sites of the catalyst are easily occupied in conditions of high concentrations of organic matter [135]. Therefore, a slight increase in the initial concentration of the substrate reduces the adsorption capacity of the photocatalyst and reduces the reaction rate.

The main purpose of altering the morphologies of photocatalyst is to reduce its band gap and increase the light response to the visible zone, as well as the recombination reduction of the electron/hole pair and increase the photocatalytic activity of semiconductors. In an effort to develop effective methods for the removal of lethal contaminants from wastewater and water treatment, the focus is on the development of a binary metal oxide catalyst supported for the photocatalytic oxidation process used in wastewater [136, 137]. In this regard, doping with correct choice of the metal ions and its optimum concentration, can be used to change the chemical, physical, optical and photocatalytic properties of raw materials in a complex way [138]. It also maintains charge separation from the electron/hole pair and keeps the photocatalyst excited for longer. However, at high concentrations, the metal can proceed as a recombination agent and disrupt the photocatalytic process [139]. Photocatalytic activity can be enhanced by increasing surface area and porosity [140], composite constitution, methodology and crystallite size reduction. The dose of photocatalyst used plays a significant role in the photocatalytic activity for pollutant degradation.

\subsection{Nitrogen fixation}

Nitrogen fixation is the operation by which molecular $\mathrm{N}_{2}$ gas is turn into reactive and biological species of nitrogen, which is a fundamental process on a global scale for survival [141]. Nitrogen fixation is a reaction performed by the Haber-Bosch process in industry to produce biomolecules. This process requires intense reaction conditions (temperature above $300^{\circ} \mathrm{C}$ and pressure $15 \mathrm{MPa}$ ) that consume a lot of energy [142]. Therefore, researchers were looking for an environmentally friendly method with moderate conditions to reduce energy consumption and a reasonable cost for nitrogen fixation [143]. Photocatalysis has shown great capability in $\mathrm{N}_{2}$ fixation as an ecofriendly technology with solar energy as the power source in the reaction process [144]. Today, the design of nanostructured photocatalysts has expanded because it provides improved photocatalytic activity due to the separation and transfer of their photogenized effect [145]. The photocatalytic activity of nanocomposites strongly depends on the shape of the loading particles, the optical band gap and the concentration of the defect [146]. Nanostructured photocatalysts often have higher specific surface area and more active sites compared with their bulk counterparts, thus being able to excite $\mathrm{N}_{2}$ molecules. It is important to select materials that can replace nitrogen voids with the photocatalytic stabilizing ability of $\mathrm{N}_{2}$. [147]. New research on Z-scheme photocatalytic systems has made semiconductor material design more logical and practical [148], which not only solves the problem of insufficient light absorption and faster recombination, but also offers chemists a wide range of perspectives. But, the selection of suitable semiconductor materials, insufficient absorption of visible light and low quantum efficiency still limit practical applications. In addition, to achieve fine-tuning at the junction of support and other photocatalysts, it is important to inspect the 
nanoparticle anchor on the support surface. Various pathways should be considered to adjust the functional capacity of the surface to enhance anchorage capability, as effective migration and separation of photocarriers is only possible through the surface bonding of intact nanocomposites.

\section{Conclusions}

In this review, we presented recent advances in the characterization, synthesis, and photocatalytic applications of vanadate photocatalysts, particularly in the field of energy supply and pollutant degradation. Over the past five years, some interesting studies on vanadate photocatalysts have been reported and highlighted. Many solutions, such as energy band engineering, doping, heterojunction structure, surface moderating, and conjunct catalyst bonding, have been used to increase light absorption, modify charge carriers, progress photocatalytic resistance, and hasten surface reaction kinetics. Several vanadate compounds as a photocatalysts have been designed and prepared, including $\mathrm{Pt}-\mathrm{BiVO}_{4}, \mathrm{Z}$-scheme $\mathrm{BiVO}_{4}$, heterojunction $\mathrm{BiVO}_{4}, \mathrm{InVO}_{4}, \mathrm{FeVO}_{4}$ heterostructure, $\mathrm{Ag}_{3} \mathrm{VO}_{4}, \mathrm{VO}_{4}$-based ternary composites. These photocatalysts are good candidates for purposes such as water distribution, pollutant degradation, water treatment, $\mathrm{CO}_{2}$ reduction, $\mathrm{N}_{2}$ stabilization and organic synthesis.

The electronic structure of the catalyst and the exposed surfaces can greatly affect the photocatalytic efficiency because photocatalytic reactions occur on the catalyst surface. Reducing electron-hole pair recombination and promoting electron transmit proficiency, both of which can generally be realized in defect-rich 2D systems, are other steps towards enhanced photocatalytic efficiency. As it turned out, the heterojunction Z-scheme design system has a better result for photocatalytic hydrogen production. In particular, the network construction of independent 3D nanotubes can enhance the separation performance of photocatalysts. Also, doping on some vanadium compounds such as $\mathrm{BiVO}_{4}$ by semiconductors such as $\mathrm{WO}_{3}, \mathrm{NiO}$ and $\mathrm{CdS}$ and using perovskite-based composites will be an important step towards achieving the goals.

However, most of the photocatalysts only respond to ultraviolet light for water splitting. Commercializing photocatalysts requires the participation of various specialized groups such as materials scientists, band gap engineers, chemists and chemical engineers. It is important to develop visible-light-responsive photocatalysts in order to harvest sunlight efficiently. Further research is needed to form binary and ternary composites to absorb light in the visible region and increase degradation by preventing electron recombination with less catalyst and time. Then, new opportunities are created to address the challenges effectively with the use of modified composites. Decreased catalytic activity over time is a usual problem for all photocatalysts, becoming a barrier to their industrial applications. The main problem to work out involves the synthesis of a large-scale, high-performance vanadate photocatalyst with high photocatalytic efficiency. For example, highly crystalline products with suitable defects exposed and active aspects were difficult to obtain in the precipitation method. The production of atomic-thick vanadium-based materials, or the conversion of nanosheets to monolayers through peeling, is a new strategy that could be used in the future. Of course, this approach is challenging because the interlayer of vanadate-based photocatalysts are absorbed by electrostatic interaction instead of van der Waals forces.

\section{References}

[1] F. Ghasemzadeh, M. Esmaeili Shayan, Nanotechnology in the Service of Solar Energy Systems, (2020). DOI: 10.5772/intechopen.93014.

[2] M. Tawalbeh, A. Al-Othman, F. Kafiah, E. Abdelsalam, et al., Environmental impacts of solar photovoltaic systems: A critical review of recent progress and future outlook, Science of The Total Environment. 759 (2021) 143528. https://doi.org/10.1016/j.scitotenv.2020.143528.

[3] S. Lee, M. Vandiver, B. Viswanathan, V. Subramanian, Harvesting Solar Energy Using Inexpensive and Benign Materials, Handbook of Climate Change Mitigation, Springer. (2012) 1217-1261. https://doi.org/10.1007/978-1-4419-7991-9_32.

[4] I.R. Segundo, E. Freitas, S. Landi Jr., M.F.M. Costa, J.O. Carneiro, Smart, Photocatalytic and Self-Cleaning Asphalt Mixtures: A Literature Review, coatings. 9 (2019) 696 https://doi.org/10.3390/coatings9110696.

[5] A. Akhoondi, A.I. Osman, A. Alizade Eslami, Direct catalytic production of dimethyl ether from $\mathrm{CO}$ and $\mathrm{CO} 2$ : A review, Synthesis and sintering. 1 (2021) 105-120. https://doi.org/10.53063/synsint.2021.1229.

[6] D. Li, X. Fang, H. Liu, H. Lu, Z. Zhang, Photo reduction of $\mathrm{CO} 2$ to $\mathrm{CH} 4$ on g-C3N4: The effect of concentrating light and pretreatment, API Conference Proceedings. 1971 (2018) 020006. https://doi.org/10.1063/1.5041101.

[7] M. Liu, G. Chen, B. Min, J. Shi, Y. Chen, Q. Liu, Photocatalytic $\mathrm{CO} 2$ Reduction, Solar-to-Chemical Conversion: Photocatalytic and Photoelectrochemcial Processes, Wiley. (2021). https://doi.org/10.1002/9783527825073.ch9.

[8] S.Y. Lee, S.J. Park, TiO2 photocatalyst for water treatment applications, Journal of Industrial and Engineering Chemistry. 19 (2013) 1761-1769. https://doi.org/10.1016/j.jiec.2013.07.012.

[9] N.J.D.G. Reyes, F.K.F. Geronimo, K.A.V. Yano, H.B. Guerra, L.H. Kim, Pharmaceutical and Personal Care Products in Different Matrices: Occurrence, Pathways, and Treatment Processes, Water. 13 (2021) 1159. https://doi.org/10.3390/w13091159.

[10] S. Zhu, D.i Wang, Photocatalysis: Basic Principles, Diverse Forms of Implementations and Emerging Scientific Opportunities, Advanced Energy Materials. 7 (2017) 1700841. https://doi.org/10.1002/aenm.201700841.

[11] S. Sakka, Handbook of Advanced Ceramics (Second Edition), SolGel Process and Applications, Academic Press. (2013) 883-910.

[12] A. Gnanaprakasam, V.M. Sivakumar, M. Thirumarimurugan, Influencing Parameters in the Photocatalytic Degradation of Organic Effluent via Nanometal Oxide Catalyst: A Review, Indian journal of Materials Science. (2015) 601827. https://doi.org/10.1155/2015/601827.

[13] S. Anoop Yadav, Nanomaterials for Air Remediation, Biological and physicochemical combination processes, Elsevier. (2020) 361-372.

[14] T.V.L. Thejaswini, D.Prabhakaran, M. AkhilaMaheswari, Soft synthesis of Bi Doped and $\mathrm{Bi}-\mathrm{N}$ co-doped TiO2 nanocomposites: A comprehensive mechanistic approach towards visible light induced ultra-fast photocatalytic degradation of fabric dye pollutant, Journal of Environmental Chemical Engineering. 4 (2016) 1308-1321. https://doi.org/10.1016/j.jece.2016.01.031.

[15] C.H.A. Tsang, K.Li, Y. Zeng, W. Zhao, et al., Titanium oxide based photocatalytic materials development and their role of in the air pollutants degradation: Overview and forecast, Environment International. 125 (2019) 200-228. https://doi.org/10.1016/j.envint.2019.01.015.

[16] S.R., Shanmugham, G.B., Jegadeesan, V. Ponnusami, Nanotechnology in the Beverage Industry, Groundwater treatments using nanomaterials, Elsevier. (2020) 25-49.

[17] G.J. Lee, J.J. Wu, Recent developments in ZnS photocatalysts from synthesis to photocatalytic applications - A review, Powder 
Technology. 318 (2017) 8-22.

https://doi.org/10.1016/j.powtec.2017.05.022.

[18] X.H., Tang, C.H., Wei, J.R., Liang, B.G., Wang, Preparation and photocatalytic activity of boron doped $\mathrm{CeO} 2 / \mathrm{TiO} 2$ mixed oxides, Huan Jing Ke Xue. 27 (2006) 1329-33.

[19] M. Nasirian, C.F. Bustillo-Lecompte, M. Mehrvar, Photocatalytic efficiency of $\mathrm{Fe} 2 \mathrm{O} 3 / \mathrm{TiO} 2$ for the degradation of typical dyes in textile industries: Effects of calcination temperature and UV-assisted thermal synthesis, J Environ Manage. 196 (2017) 487-498. https://doi.org/10.1016/j.jenvman.2017.03.030.

[20] D. Pan, Z. Han, Y. Miao, D. Zhang, G. Li, Thermally stable TiO2 quantum dots embedded in $\mathrm{SiO} 2$ foams: Characterization and photocatalytic $\mathrm{H} 2$ evolution activity, Applied Catalysis B: Environmental. 229 (2018) 130-138. https://doi.org/10.1016/j.apcatb.2018.02.022.

[21] J. Guo, J. Liang, X. Yuan, L. Jiang, G. Zeng, H. Yu, J. Zhang, Efficient visible-light driven photocatalyst, silver (meta) vanadate: Synthesis, morphology and modification, Chemical Engineering Journal. 352 (2018) 782-802. https://doi.org/10.1016/j.cej.2018.07.071.

[22] A.P. Singh, N. Kodan, B.R. Mehta, A. Held, et al., Band Edge Engineering in BiVO4/TiO2 Heterostructure: Enhanced Photoelectrochemical Performance through Improved Charge Transfer, ACS Catalysis. 6 (2016) 5311-5318. https://doi.org/10.1021/acscatal.6b00956.

[23] V.H. Nguyen, M. Mousavi, J.B. Ghasemi, Q.V. Le, S.A. Delbari, A. Sabahi Namini, M. Shahedi Asl, M. Shokouhimehr, M. Mohammadi, Novel $\mathrm{p}-\mathrm{n}$ Heterojunction Nanocomposite: TiO2 QDs/ZnBi2O4 Photocatalyst with Considerably Enhanced Photocatalytic Activity under Visible-Light Irradiation, J. Phys. Chem. C. 50 (2020) 27519 27528. https://doi.org/10.1021/acs.jpcc.0c08316.

[24] G. Hu, J. Yang, X. Duan, R. Farnood, C. Yang, J. Yang, W. Liu, Q. Liu, Recent developments and challenges in zeolite-based composite photocatalysts for environmental applications, Chemical Engineering Journal. 417 (2021) 129209. https://doi.org/10.1016/j.cej.2021.129209.

[25] R. Ameta, M.S. Solanki, S. Benjamin, S.C. Ameta, Photocatalysis, Advanced Oxidation Processes for Waste Water Treatment, Academic Press. (2018) 135-175. https://doi.org/10.1016/B978-0-12810499-6.00006-1.

[26] B.J. Ng, L.K. Putri, X.Y. Kong, Y.W. Teh, et al., Z-Scheme Photocatalytic Systems for Solar Water Splitting, Advanced sciense. 7 (2020) 1903171. https://doi.org/10.1002/advs.201903171.

[27] B. Bajorowicz, M.P. Kobylański, A. Malankowska, P. Mazierski, J. Nadolna, A. Pieczyńska, A. Zaleska-Medynska, Metal Oxide-Based Photocatalysis, Application of metal oxide-based photocatalysis, Elsevier. (2018) 211-340.

[28] M. Xie, X. Fu, L. Jing, P. Luan, Y. Feng, H. Fu, Long-Lived, Visible-Light-Excited Charge Carriers of TiO2/BiVO4 Nanocomposites and their Unexpected Photoactivity for Water Splitting, Advanced Energy Materials. 4 (2014) 1300995. https://doi.org/10.1002/aenm.201300995.

[29] M.J. Abel, A. Pramothkumar, N. Senthilkumar, et al., Flake-like $\mathrm{CuMn} 2 \mathrm{O} 4$ nanoparticles synthesized via co-precipitation method for photocatalytic activity, Physica B: Condensed Matter. 572 (2019) 117-124. https://doi.org/10.1016/j.physb.2019.07.047.

[30] V.S. Kirankumar, S. Sumathi, A review on photodegradation of organic pollutants using spinel oxide, Materialstoday. 18 (2020) 100355. https://doi.org/10.1016/j.mtchem.2020.100355.

[31] J.K. Guo, J. Li, H.M. Kou, Chapter 17-Advanced Ceramic Materials, Modern Inorganic Synthetic Chemistry (Second Edition), Elsevier. (2017) 463-492. https://doi.org/10.1016/B978-0-444-63591-4.000173.

[32] A.N. El-Shazly, M.M. Rashad, E.A. Abdel-Aal, I.A. Ibrahim, M.F. El-Shahat, A.E. Shalan, Nanostructured $\mathrm{ZnO}$ photocatalysts prepared via surfactant assisted Co-Precipitation method achieving enhanced photocatalytic activity for the degradation of methylene blue dyes,
Journal of Environmental Chemical Engineering. 4 (2016) 3177

3184. https://doi.org/10.1016/j.jece.2016.06.018.

[33] X. You, F. Chen, J. Zhang, M. Anpo, A novel deposition precipitation method for preparation of Ag-loaded titanium dioxide, Catalysis Letters. 102 (2005) 247-250

https://doi.org/10.1007/s10562-005-5863-5.

[34] P. Dumrongrojthanath, A. Phuruangrat, S. Thongtem, T. Thongtem, Photocatalysis of Cd-doped $\mathrm{ZnO}$ synthesized with precipitation method, Rare Metals. 40 (2021) 537-546. https://doi.org/10.1007/s12598-019-01283-6.

[35] S. Liu, C. Ma, M.G. Ma, F. Xu, Magnetic Nanocomposite Adsorbents, Composite Nanoadsorbents, Elsevier. (2019) 295-316. https://doi.org/10.1016/B978-0-12-814132-8.00013-7.

[36] C.Y. Teh, T.Y. Wu, J.C. Juan, An application of ultrasound technology in synthesis of titania-based photocatalyst for degrading pollutant, Chem. eng. J. 317 (2017) 586-612. https://doi.org/10.1016/j.cej.2017.01.001.

[37] G. Huang, C.H. Lu, H.H. Yang, Magnetic Nanomaterials for Magnetic Bioanalysis, Novel Nanomaterials for Biomedical, Environmental and Energy Applications, Elsevier. (2019) 89-109. https://doi.org/10.1016/B978-0-12-814497-8.00003-5.

[38] J.J. Ng, K.H. Leong, L.C. Sim, W.D. Oh et al., Environmental remediation using nano-photocatalyst under visible light irradiation: the case of bismuth phosphate, Elsevier. (2020) 193-207. https://doi.org/10.1016/B978-0-12-818821-7.00010-5.

[39] Q. Han, Advances in preparation methods of bismuth-based photocatalysts, Chem. eng. J. 414 (2021) 127877. https://doi.org/10.1016/j.cej.2020.127877.

[40] M. Parashar, V.K. Shukla, R. Singh, Metal oxides nanoparticles via sol-gel method: a review on synthesis, characterization and applications, Journal of Materials Science: Materials in Electronics. 31 (2020) 3729-3749. https://doi.org/10.1007/s10854-020-02994-8.

[41] Q. Liang, X. Liu, G. Zeng, Z. Liu, L. Tang, et al., Surfactant-assisted synthesis of photocatalysts: Mechanism, synthesis, recent advances and environmental application, Chem. eng. J. 372 (2019) 429-451. https://doi.org/10.1016/j.cej.2019.04.168.

[42] O. Monfort, G. Plesch, Bismuth vanadate-based semiconductor photocatalysts: a short critical review on the efficiency and the mechanism of photodegradation of organic pollutants, Environmental Science and Pollution Research. 25 (2018) 19362 19379. https://doi.org/10.1007/s11356-018-2437-9.

[43] A.J. Josephine, C.R. Dhas, R. Venkatesh, D. Arivukarasan, et al., Effect of $\mathrm{pH}$ on visible-light-driven photocatalytic degradation of facile synthesized bismuth vanadate nanoparticles, Materials Research Express. 7 (2020) 015036. https://orcid.org/0000-00017529-5972.

[44] M. Zahid, N. Nadeem, N. Tahir, Hybrid nanomaterials for water purification, Multifunctional Hybrid Nanomaterials for Sustainable Agri-Food and Ecosystems, Elsevier. (2020) 155-188. https://doi.org/10.1016/B978-0-12-821354-4.00007-8.

[45] A.M. de la Cruz, U.M. GarcíaPérez, Photocatalytic properties of BiVO4 prepared by the co-precipitation method: Degradation of rhodamine $\mathrm{B}$ and possible reaction mechanisms under visible irradiation. 45 (2010) 135-141. https://doi.org/10.1016/j.materresbull.2009.09.029.

[46] Z. Wang, X. Huang, X. Wang, Recent progresses in the design of BiVO4-based photocatalysts for efficient solar water splitting, 335 (2019) 31-38. https://doi.org/10.1016/j.cattod.2019.01.067.

[47] W. Yin, W. Wang, M. Shang, L. Zhou, S. Sun, L. Wang, BiVO4 Hollow Nanospheres: Anchoring Synthesis, Growth Mechanism, and Their Application in Photocatalysis, EurJIC. 2009 (2009) 4379-4384. https://doi.org/10.1002/ejic.200900614.

[48] W. Shi, Y. Yan, X. Yan, Microwave-assisted synthesis of nano-scale BiVO4 photocatalysts and their excellent visible-light-driven photocatalytic activity for the degradation of ciprofloxacin, Chem. Eng. J. 215-216 (2013) 740-746. https://doi.org/10.1016/j.cej.2012.10.071. 
[49] M. J. Madiabu, J. Gunlazuardi, Preparation and characterization of TiO2/BiVO4 composite: Can this photocatalyst, under visible light, be able to eliminate rhodamine B from water and why?, AIP Conference Proceedings. 2023 (2018) 020079. https://doi.org/10.1063/1.5064076.

[50] P.P. Liu, X. Liu, X.H. Huo, Y. Tang, J. Xu, H. Ju, TiO2-BiVO4 Heterostructure to Enhance Photoelectrochemical Efficiency for Sensitive Aptasensing, ACS Appl. Mater. Interfaces. 9 (2017) 27185-27192. https://doi.org/10.1021/acsami.7b07047.

[51] S. Mansour, R. Akkari, E. Soto, S.B. Chaabene, N. Mota, et al. Pt$\mathrm{BiVO} / \mathrm{TiO} 2$ composites as Z-scheme photocatalysts for hydrogen production from ethanol: the effect of BiVO4 and Pt on the photocatalytic efficiency, New Journal of Chemistry. 45 (2021) 4481-4495. https://doi.org/10.1039/D0NJ05596D.

[52] H. Hou, L. Wang, F. Gao, X. Yang, W. Yang, BiVO4@TiO2 coreshell hybrid mesoporous nanofibers towards efficient visible-lightdriven photocatalytic hydrogen production, Journal of Materials Chemistry C. 7 (2019) 7858-7864. https://doi.org/10.1039/C9TC02480H.

[53] H. Gao, P. Zhang, J. Zhao, Y. Zhang, et al., Plasmon enhancement on photocatalytic hydrogen production over the Z-scheme photosynthetic heterojunction system, Applied Catalysis B: Environmental. 210 (2017) 297-305. https://doi.org/10.1016/j.apcatb.2017.03.050.

[54] K. Bad'urová, O. Monfort, L. Satrapinskyy, E. Dworniczek, et al., Photocatalytic activity of Ag3PO4 and some of its composites under non-filtered and UV-filtered solar-like radiation, Ceramics International. 43 (2017) 3706-3712. https://doi.org/10.1016/j.ceramint.2016.11.217.

[55] S. Chen, D. Huang, G. Zeng, W. Xue, In-situ synthesis of facetdependent BiVO4/Ag3PO4/PANI photocatalyst with enhanced visible-light-induced photocatalytic degradation performance: Synergism of interfacial coupling and hole-transfer, Chemical Engineering Journal. 382 (2020) 122840. https://doi.org/10.1016/j.cej.2019.122840.

[56] Y. Bi, H. Hu, S. Ouyang, Z. Jiao, G. Lu, J. Ye, Selective growth of Ag3PO4 submicro-cubes on Ag nanowires to fabricate necklace-like heterostructures for photocatalytic applications, Journal of Materials Chemistry. 22 (2012) 14847-14850. https://doi.org/10.1039/C2JM32800C.

[57] C. Li, P. Zhang, R. Lv, J. Lu, et al., Selective Deposition of Ag3PO4 on Monoclinic BiVO4(040) for Highly Efficient Photocatalysis, Micro and Nano: No Small Matter. 9 (2013) 3951-3956. https://doi.org/10.1002/smll.201301276.

[58] W. Chen, M. Liu, X. Li, L. Mao, Synthesis of 3D mesoporous gC3N4 for efficient overall water splitting under a Z-scheme photocatalytic system, Applied surface science. 512 (2020) 145782. https://doi.org/10.1016/j.apsusc.2020.145782.

[59] N. Tian, H. Huang, Y. He, et al., Mediator-free direct Z-scheme photocatalytic system: BiVO4/g-C3N4 organic-inorganic hybrid photocatalyst with highly efficient visible-light-induced photocatalytic activity, Dalton Transactions. 44 (2015) 4297-4307. https://doi.org/10.1039/C4DT03905J.

[60] P. Niu, J. Dai, X. Zhi, Z. Xia, S. Wang, L. Li, Photocatalytic overall water splitting by graphitic carbon nitride, Info Mat. (2021). https://doi.org/10.1002/inf2.12219.

[61] D.J. Martin, P.J.T. Reardon, S.J.A. Moniz, J. Tang, Visible LightDriven Pure Water Splitting by a Nature-Inspired Organic Semiconductor-Based System, Journal of the American Chemical Society, 136 (2014) 12568-12571. https://doi.org/10.1021/ja506386e.

[62] V.H. Nguyen, M. Mousavi, J.B. Ghasemi, Q.V. Le, S.A. Delbari, A. Sabahi Namini, M. Shahedi Asl, et al., g-C3N4 nanosheet adorned with $\mathrm{Ag} 3 \mathrm{BiO} 3$ as a perovskite: An effective photocatalyst for efficient visible-light photocatalytic processes, Materials Science in Semiconductor Processing. 125 (2021) 105651. https://doi.org/10.1016/j.mssp.2020.105651.
[63] Y. Hong, Y. Jiang, C. Li et al., In-situ synthesis of direct solid-state Z-scheme V2O5/g-C3N4 heterojunctions with enhanced visible light efficiency in photocatalytic degradation of pollutants, Applied Catalysis B: environmental. 180 (2016) 663-673. https://doi.org/10.1016/j.apcatb.2015.06.057.

[64] T. Zhang, X. Shao, D. Zhang, X. Pu, et al., Synthesis of direct Zscheme g-C3N4/Ag2VO2PO4 photocatalysts with enhanced visible light photocatalytic activity, Separation and Purification Technology. 195 (2018) 332-338. https://doi.org/10.1016/j.seppur.2017.12.018.

[65] X. Sun, X. Zhang, Y. Xie, Surface Defects in Two-Dimensional Photocatalysts for Efficient Organic Synthesis, Matter. 2 (2020) 842 861. https://doi.org/10.1016/j.matt.2020.02.006.

[66] N.T. Padmanabhan, N. Thomas, J. Louis, D.T. Mathew, et al., Graphene coupled $\mathrm{TiO} 2$ photocatalysts for environmental applications: A review, Chemosphere. 271 (2021) 129506. https://doi.org/10.1016/j.chemosphere.2020.129506.

[67] S. Zhang, J. Li, X. Wang, Y. Huang, et al., Rationally designed 1D $\mathrm{Ag} @ \mathrm{AgVO} 3$ nanowire/graphene/protonated g-C3N4 nanosheet heterojunctions for enhanced photocatalysis via electrostatic selfassembly and photochemical reduction methods, J. Mater. Chem. A. 3 (2015) 10119-10126. https://doi.org/10.1039/C5TA00635J.

[68] Y. Zhao, S. Zhang, R. Shi, G.I.N. Waterhouse, et al., Twodimensional photocatalyst design: A critical review of recent experimental and computational advances, materialstoday. 34 (2020) 78-91. https://doi.org/10.1016/j.mattod.2019.10.022.

[69] Q. Jia, A. Iwase, A. Kudo, BiVO4-Ru/SrTiO3:Rh composite Zscheme photocatalyst for solar water splitting, Chem. Sci. 5 (2014) 1513. https://doi.org/10.1039/C3SC52810C.

[70] Y. Yan, X. Liu, W. Fan, P. Lv, W. Shi, InVO4 microspheres: Preparation, characterization and visible-light-driven photocatalytic activities, Chemical Engineering Journal. 200-202 (2012) 310-316. https://doi.org/10.1016/j.cej.2012.05.102.

[71] J. Shen, X. Li, W. Huang, N. Li, M. Ye, Synthesis of novel photocatalytic RGO-InVO4 nanocomposites with visible light photoactivity, Materials Research Bulletin, 48 (2013) 3112-3116. https://doi.org/10.1016/j.materresbull.2013.04.077.

[72] X. Lin, D. Xu, J. Zheng, M. Song, G. Che, et al., Graphitic carbon nitride quantum dots loaded on leaf-like InVO4/BiVO4 nanoheterostructures with enhanced visible-light photocatalytic activity, Journal of Alloys and Compounds, 688 (2016) 891-898. https://doi.org/10.1016/j.jallcom.2016.07.275.

[73] S. Chaudhary, Y. Kaur, B. Jayee, G. R. Chaudhary, A. Umar, NiO nanodisks: Highly efficient visible-light driven photocatalyst, potential scaffold for seed germination of Vigna Radiata and antibacterial properties, J. of Cleaner Production. 190 (2018) 563576. https://doi.org/10.1016/j.jclepro.2018.04.110.

[74] N.M. Hosny, Synthesis, characterization and optical band gap of $\mathrm{NiO}$ nanoparticles derived from anthranilic acid precursors via a thermal decomposition route, Polyhedron. 30 (2011) 470-476. https://doi.org/10.1016/j.poly.2010.11.020.

[75] H.Y. Lin, Y.F. Chen, Y.W. Chen, Water splitting reaction on $\mathrm{NiO} / \mathrm{InVO} 4$ under visible light irradiation, International Journal of Hydrogen Energy. 32 (2007) 86-92. https://doi.org/10.1016/j.ijhydene.2006.04.007.

[76] N.M. Hosny, I. Gomaa, A. Abd El-Moemen, Z.M. Anwar, Synthesis, magnetic and adsorption of dye onto the surface of $\mathrm{NiO}$ nanoparticles, Journal of Materials Science: Materials in Electronics. 31 (2020) 8413-8422. https://doi.org/10.1007/s10854-020-03376-w.

[77] Z. Wei, T. Xinyue, W. Xiaomeng et al., Novel p-n heterojunction photocatalyst fabricated by flower-like BiVO4 and Ag2S nanoparticles: Simple synthesis and excellent photocatalytic performance, Chem. Eng. Journal. 361 (2019) 1173-1181. https://doi.org/10.1016/j.cej.2018.12.120.

[78] M.E. Aguirre, R. Zhou, A.J. Eugene, M.I. Guzman, M.A. Grela, $\mathrm{Cu} 2 \mathrm{O} / \mathrm{TiO} 2$ heterostructures for $\mathrm{CO} 2$ reduction through a direct $\mathrm{Z}$ scheme: Protecting $\mathrm{Cu} 2 \mathrm{O}$ from photocorrosion, Applied Catalysis B: 
Environmental. 217 (2017) 485-493.

https://doi.org/10.1016/j.apcatb.2017.05.058.

[79] W. Wang, X. Huang, S. Wu, Y. Zhou, et al., Preparation of p-n junction $\mathrm{Cu} 2 \mathrm{O} / \mathrm{BiVO} 4$ heterogeneous nanostructures with enhanced visible-light photocatalytic activity, Applied Catalysis B:

Environmental. 134-135 (2013) 293-301. https://doi.org/10.1016/j.apcatb.2013.01.013.

[80] Y. Zheng, Y. Chen, B. Gao, B. Lin, X. Wang, Phosphorene-Based Heterostructured Photocatalysts, Engineering. (2021). https://doi.org/10.1016/j.eng.2021.06.004.

[81] M. Zhu, Z. Sun, M. Fujitsuka, T. Majima, Inside Cover: Z-Scheme Photocatalytic Water Splitting on a 2D Heterostructure of Black Phosphorus/Bismuth Vanadate Using Visible Light, Angewandte Chemie. 57 (2018) 2008. https://doi.org/10.1002/anie.201800579.

[82]M.B.R. Kamalam, S.S.R. Inbanathan, K. Sethuraman, A. Umar, et al., Direct sunlight-driven enhanced photocatalytic performance of V2O5 nanorods/ graphene oxide nanocomposites for the degradation of Victoria blue dye, Environmental Research. 199 (2021) 111369. https://doi.org/10.1016/j.envres.2021.111369.

[83] Y. Min, K. Zhang, Y. Chen, Y. Zhang, Synthesis of novel visible light responding vanadate/ $\mathrm{TiO} 2$ heterostructure photocatalysts for application of organic pollutants, Chemical Engineering Journal. 175 (2011) 76-83. https://doi.org/10.1016/j.cej.2011.09.042.

[84] Y.R. Lv, C.J. Liu, R.K. He, X. Li, Y.H. Xu, BiVO4/TiO2 heterojunction with enhanced photocatalytic activities and photoelectochemistry performances under visible light illumination, Materials Research Bulletin. 117 (2019) 35-40. https://doi.org/10.1016/j.materresbull.2019.04.032.

[85] M. Zhu, Z. Sun, M. Fujitsuka, T. Majima, Z-Scheme Photocatalytic Water Splitting on a 2D Heterostructure of Black Phosphorus/Bismuth Vanadate Using Visible Light, Angewandte chemie. 130 (2018) 2182-2186 https://doi.org/10.1002/ange.201711357.

[86] M. Wang, Q. Wang, P. Guo, Z. Jiao, In situ fabrication of nanoporous $\mathrm{BiVO} 4 / \mathrm{Bi} 2 \mathrm{~S} 3$ nanosheets for enhanced photoelectrochemical water splitting, Journal of Colloid and Interface Science. 534 (2019) 338-342. https://doi.org/10.1016/j.jcis.2018.09.056.

[87] T.W. Kim, K.S., Choi, Improving Stability and Photoelectrochemical Performance of BiVO4 Photoanodes in Basic Media by Adding a ZnFe2O4 Layer, The Journal of Physical Chemistry Letters. 7 (2016) 447-451. https://doi.org/10.1021/acs.jpclett.5b02774.

[88] L. Zhang, C.Y. Lin, V.K. Valev, E. Reisner, U. Steiner, J.J. Baumberg, Plasmonic Enhancement in BiVO4 Photonic Crystals for Efficient Water Splitting, Nano.Micro.samll. 10 (2014) 3970-3978. https://doi.org/10.1002/smll.201400970.

[89] Y. Pihosh, I. Turkevych, K. Mawatari, J. Uemura, et al., Photocatalytic generation of hydrogen by core-shell WO3/BiVO4 nanorods with ultimate water splitting efficiency, scientific report. 5 (2015) 11141. https://doi.org/10.1038/srep11141.

[90] Z. Jiao, J. Zheng, C. Feng, Z. Wang, et al., Fe/W Co-Doped BiVO4 Photoanodes with a Metal-Organic Framework Cocatalyst for Improved Photoelectrochemical Stability and Activity, Chemsunchem. 9 (2016) 2824-2831. https://doi.org/10.1002/cssc.201600761.

[91] R. Li, H. Han, F. Zhang, D. Wang, C. Li, Highly efficient photocatalysts constructed by rational assembly of dual-cocatalysts separately on different facets of BiVO4, Energy \& Environmental Science. 7 (2014) 1369-1376. https://doi.org/10.1039/C3EE43304H.

[92] T. Lv, D. Li, Y. Hong, B. Luo, D. Xu, M. Chen, W. Shi, Facile synthesis of CdS/Bi4V2O11 photocatalysts with enhanced visiblelight photocatalytic activity for degradation of organic pollutants in water, Dalton Transactions. 46 (2017) 12675-12682. https://doi.org/10.1039/C7DT02151H.

[93] L.Z. Pei, N. Lin, T. Wei, H.Y. Yu, Synthesis of manganese vanadate nanobelts and their visible light photocatalytic activity for methylene blue, Journal of Experimental Nanoscience. 11 (2016) 197-214. https://doi.org/10.1080/17458080.2015.1047418.

[94] S. Bao, Z. Wang, J. Zhang, B. Tian, Facet-Heterojunction-Based ZScheme BiVO4 $\{010\}$ Microplates Decorated with AgBr-Ag Nanoparticles for the Photocatalytic Inactivation of Bacteria and the Decomposition of Organic Contaminants, ACS Appl. Nano Mater. 3 (2020) 8604-8617. https://doi.org/10.1021/acsanm.0c00703.

[95] M. Tayebi, A. Tayyebi, T. Soltani, B.K. Lee, pH-Dependent photocatalytic performance of modified bismuth vanadate by bismuth ferrite, New Journal of Chemistry. 43 (2019) 9106-9115. https://doi.org/10.1039/C9NJ00214F.

[96] P. Li, N. Umezawa, H. Abe, J. Ye, Novel visible-light sensitive vanadate photocatalysts for water oxidation: implications from density functional theory calculations, Journal of Materials Chemistry A. 3 (2015) 10720-10723. https://doi.org/10.1039/C5TA01416F.

[97] V.H. Nguyen, B.S. Nguyen, C. Hu, C.C. Nguyen, D.L.T. Nguyen, M.T.N. Dinh, D.V.N. Vo, Q.T. Trinh, M. Shokouhimehr, A. Hasani, S.Y. Kim, Q.V. Le, Novel Architecture Titanium Carbide (Ti3C2Tx) MXene Cocatalysts toward Photocatalytic Hydrogen Production:, A Mini-Review, Nanomaterials. 10 (2020) 602. https://doi.org/10.3390/nano10040602.

[98] S.S. Lam, V.H. Nguyen, M.T.N. Dinh, D.Q. Khieu, D.D. La, H.T Nguyen, D.V.N. Vo, C. Xia, R.S. Varma, M. Shokouhimehr, C.C. Nguyen, Q.V. Le, W. Peng, Mainstream avenues for boosting graphitic carbon nitride efficiency: towards enhanced solar lightdriven photocatalytic hydrogen production and environmental remediation, Journal of Materials Chemistry A. 8 (2020) 1057110603. https://doi.org/10.1039/D0TA02582H.

[99] H. Gao, P. Zhang, J. Zhao, Y. Zhang, J. Hu, G. Shao, Plasmon enhancement on photocatalytic hydrogen production over the $Z$ scheme photosynthetic heterojunction system, Applied Catalysis B: Environmental. 210 (2017) 297-305. https://doi.org/10.1016/j.apcatb.2017.03.050.

[100] H. Yan, J. Yang, G. Ma, G. Wu, et al., Visible-light-driven hydrogen production with extremely high quantum efficiency on $\mathrm{Pt}-$ PdS/CdS photocatalyst, Journal of Catalysis. 266 (2009) 165-168. https://doi.org/10.1016/j.jcat.2009.06.024.

[101] A.M. Huerta-Flores, L.M. Torres-Martínez, D. SánchezMartínez, M.E. Zarazúa-Morín, SrZrO3 powders: Alternative synthesis, characterization and application as photocatalysts for hydrogen evolution from water splitting, Fuel. 158 (2015) 66-71. https://doi.org/10.1016/j.fuel.2015.05.014.

[102] S. Sreekantan, K.A. Saharudin, N. Basiron, L.C. Wei, Newgeneration titania-based catalysts for photocatalytic hydrogen generation, Nanostructured, Functional, and Flexible Materials for Energy Conversion and Storage Systems, Elsevier. (2020) 257-292 . https://doi.org/10.1016/B978-0-12-819552-9.00008-7.

[103] R. Li, C. Li, Photocatalytic Water Splitting on SemiconductorBased Photocatalysts, Advances in Catalysis, 60 (2017) 1-57. https://doi.org/10.1016/bs.acat.2017.09.001.

[104] H. Wang, X. Liu, P. Niu, S. Wang, J. Shi, L. Li, Porous TwoDimensional Materials for Photocatalytic and Electrocatalytic Applications, Matter. 2 (2020) 1377-1413. https://doi.org/10.1016/j.matt.2020.04.002.

[105] X. Zhao, S. Chen, H. Yin, S. Jiang, et al., Perovskite Microcrystals with Intercalated Monolayer MoS2 Nanosheets as Advanced Photocatalyst for Solar-Powered Hydrogen Generation, Matter. 3 (2020) 935-949. https://doi.org/10.1016/j.matt.2020.07.004.

[106] Y. Wang, X. Shang, J. Shen, Z. Zhang et al., Direct and indirect $\mathrm{Z}$-scheme heterostructure-coupled photosystem enabling cooperation of $\mathrm{CO} 2$ reduction and $\mathrm{H} 2 \mathrm{O}$ oxidation, 11 (2020) 3043 https://doi.org/10.1038/s41467-020-16742-3.

[107] Q. Xu, L. Zhang, J. Yu, S. Wageh, et al., Direct Z-scheme photocatalysts: Principles, synthesis, and applications, materialstoday. 21 (2018) 1042-1063. https://doi.org/10.1016/j.mattod.2018.04.008. 
[108] Z. Lei, G. Ma, M. Liu, W. You, H. Yan, Sulfur-substituted and zinc-doped $\mathrm{In}(\mathrm{OH}) 3$ : A new class of catalyst for photocatalytic $\mathrm{H} 2$ production from water under visible light illumination, Journal of Catalysis. 237 (2006) 322-329. https://doi.org/10.1016/j.jcat.2005.11.022.

[109] X. Ren, M. Gao, Y. Zhang, Z. Zhang, et al., Photocatalytic reduction of $\mathrm{CO} 2$ on $\mathrm{BiOX}$ : Effect of halogen element type and surface oxygen vacancy mediated mechanism, Applied Catalysis B: Environmental. 274 (2020) 119063. https://doi.org/10.1016/j.apcatb.2020.119063.

[110] J. Bi, B. Xu, L. Sun, H. Huang et al., A Cobalt-Modified Covalent Triazine-Based Framework as an Efficient Cocatalyst for Visible-Light-Driven Photocatalytic CO2 Reduction, 84 (2019) 1149-1154. http://dx.doi.org/10.1002/cplu.201900329.

[111] C. Prasad, X. Yang, Q. Liu, H. Tang, et al., Recent advances in MXenes supported semiconductors based photocatalysts: Properties, synthesis and photocatalytic applications, Journal of Industrial and Engineering Chemistry. 85 (2020) 1-33. https://doi.org/10.1016/j.jiec.2019.12.003.

[112] X. Chang, T. Wang, J. Gong, CO2 photo-reduction: insights into $\mathrm{CO} 2$ activation and reaction on surfaces of photocatalysts, Energy \& Environmental Science.9 (2016) 2177-2196. https://doi.org/10.1039/C6EE00383D.

[113] Y.F. Xu, M.Z. Yang, B.X. Chen, X.D. Wang, et al., A CsPbBr 3 Perovskite Quantum Dot/Graphene Oxide Composite for Photocatalytic CO2 Reduction, J Am Chem Soc. 139 (2017) 56605663. https://doi.org/10.1021/jacs.7b00489.

[114] H. Nakanishi, K. Iizuka, T. Takayama, A. Iwase, A. Kudo, Highly Active NaTaO3-Based Photocatalysts for CO2 Reduction to Form CO Using Water as the Electron Donor, ChemSusChem. 10 (2017) 112-118. https://doi.org/10.1002/cssc.201601360.

[115] R. Kumar, A. Umar, D.S. Rana, P. Sharma, et al., Fe-doped $\mathrm{ZnO}$ nanoellipsoids for enhanced photocatalytic and highly sensitive and selective picric acid sensor, Materials Research Bulletin. 102 (2018) 282-288. https://doi.org/10.1016/j.materresbull.2018.02.042.

[116] S.P. Patil, R.P. Patil, V.K. Mahajan, G.H. Sonawane, V.S. Shrivastava, S. Sonawane, Facile sonochemical synthesis of BiOBrgraphene oxide nanocomposite with enhanced photocatalytic activity for the degradation of Direct green, Materials Science in Semiconductor Processing. 52 (2016) 55-61. https://doi.org/10.1016/j.mssp.2016.05.008.

[117] V.H. Nguyen, B.S. Nguyen, Z. Jin, M. Shokouhimehr, H.W. Jang, C. Hu, P. Singh, P. Raizada, W. Peng, S.S. Lam, C. Xia, C.C. Nguyen, S.Y. Kim, Q.V. Le,," Towards artificial photosynthesis: Sustainable hydrogen utilization for photocatalytic reduction of $\mathrm{CO} 2$ to high-value renewable fuels, Chemical Engineering Journal. 402 (2020) 126184. https://doi.org/10.1016/j.cej.2020.126184.

[118] T.P. Nguyen, D.M.T. Nguyen, D.L. Tran, H.K. Le, D.V.N. Vo, S.S. Lam, R.S. Varma, M. Shokouhimehr, C.C. Nguyen, Q.V.Le, MXenes: Applications in electrocatalytic, photocatalytic hydrogen evolution reaction and $\mathrm{CO} 2$ reduction, Molecular Catalysis. 486 (2020) 110850. https://doi.org/10.1016/j.mcat.2020.110850.

[119] B.G. Oliver, J.H. Carey, Photodegradation of Wastes and Pollutants in Aquatic Environment, Springer, Dordrecht. (1986) 629650. https://doi.org/10.1007/978-94-009-4642-2_36.

[120] Y. Paz, Application of $\mathrm{TiO} 2$ photocatalysis for air treatment: Patents' overview, Applied catalysis B: environmental. 99 (2010) 448-460. https://doi.org/10.1016/j.apcatb.2010.05.011.

[121] Y. Boyjoo, H. Sun, J. Liu, V.K. Pareek, S. Wang, A review on photocatalysis for air treatment: From catalyst development to reactor design, Chem. Eng. J. 310 (2017) 537-559. https://doi.org/10.1016/j.cej.2016.06.090.

[122] Y. Hu, W. Chen, J. Fu, M. Ba, F. Sun, et al., Hydrothermal synthesis of $\mathrm{BiVO} 4 / \mathrm{TiO} 2$ composites and their application for degradation of gaseous benzene under visible light irradiation, Applied surface science. 436 (2018) 319-326. https://doi.org/10.1016/j.apsusc.2017.12.054.
[123] T.P.Shende, B.A.Bhanvase, A.P.Rathod, D.V.Pinjari, S.H.Sonawane, Sonochemical synthesis of Graphene-Ce-TiO2 and Graphene-Fe-TiO2 ternary hybrid photocatalyst nanocomposite and its application in degradation of crystal violet dye, Ultrasonics Sonochemistry. 41 (2018) 582-589. https://doi.org/10.1016/j.ultsonch.2017.10.024.

[124] P. Taneja, S. Sharma, A. Umar, S.K. Mehta, et al., Visible-light driven photocatalytic degradation of brilliant green dye based on cobalt tungstate (CoWO4) nanoparticles, Materials Chemistry and Physics. 211 (2018) 335-342.

https://doi.org/10.1016/j.matchemphys.2018.02.041.

[125] B. Bethi, S.H. Sonawane, G.S. Rohit, C.R. Holkar, et al., Investigation of $\mathrm{TiO} 2$ photocatalyst performance for decolorization in the presence of hydrodynamic cavitation as hybrid AOP, Ultrasonics Sonochemistry. 28 (2016) 150-160. https://doi.org/10.1016/j.ultsonch.2015.07.008.

[126] M. Malakootian, A. Nasiri, M. Khatami, H. Mahdizadeh, et al., Experimental data on the removal of phenol by electro- $\mathrm{H} 2 \mathrm{O} 2$ in presence of UV with response surface methodology, MethodsX. 6 (2019) 1188-1193. https://doi.org/10.1016/j.mex.2019.05.004.

[127] S. Sharma, A. Umar, S.K. Mehta, A.O. Ibhadon, S.K. Kansal, Solar light driven photocatalytic degradation of levofloxacin using TiO2/carbon-dot nanocomposites, New Journal of Chemistry. 42 (2018) 7445-7456. https://doi.org/10.1039/C7NJ05118B.

[128] F. Tamaddon, A. Nasiri, G. Yazdanpanah, Photocatalytic degradation of ciprofloxacin using CuFe2O4@methyl cellulose based magnetic nanobiocomposite, MethodsX. 7 (2020) 100764. https://doi.org/10.1016/j.mex.2019.12.005.

[129] W. Somraksa, S. Suwanboon, P. Amornpitoksuk, C. Randorn, Physical and Photocatalytic Properties of $\mathrm{CeO} 2 / \mathrm{ZnO} / \mathrm{ZnA} 2 \mathrm{O} 4$ Ternary Nanocomposite Prepared by Co-precipitation Method, Mat. Res. 23 (2020). https://doi.org/10.1590/1980-5373-MR-2019-0627.

[130] B.A. Bhanvase, T.P. Shende, S.H. Sonawane, A review on graphene- $\mathrm{TiO} 2$ and doped graphene- $\mathrm{TiO} 2$ nanocomposite photocatalyst for water and wastewater treatment, Environmental Technology Reviews. 6 (2017) 1-14. https://doi.org/10.1080/21622515.2016.1264489.

[131] E. Kusiak-Nejman, A. Wanag, J. Kapica- Kozar, Ł. Kowalczyk, et al. Methylene blue decomposition on $\mathrm{TiO} 2 /$ reduced graphene oxide hybrid photocatalysts obtained by a two-step hydrothermal and calcination synthesis, Catalysis Today. 357 (2020) 630-637. https://doi.org/10.1016/j.cattod.2019.04.078.

[132] P.K. Labhane, L.B. Patle, G.H. Sonawane, S.H. Sonawane, Fabrication of ternary $\mathrm{Mn}$ doped $\mathrm{ZnO}$ nanoparticles grafted on reduced graphene oxide (RGO) sheet as an efficient solar light driven photocatalyst, Chemical Physics Letters. 710 (2018) 70-77. https://doi.org/10.1016/j.cplett.2018.08.066.

[133] D.N. Yadav, K.A. Kishore, B. Bethi, S.H. Sonawane, D. Bhagawan, $\mathrm{ZnO}$ nanophotocatalysts coupled with ceramic membrane method for treatment of Rhodamine-B dye waste water, Environment, Development and Sustainability. 20 (2018) 2065-2078. https://doi.org/10.1007/s10668-017-9977-x.

[134] B.C.B. Salgado, R.A. Cardeal, A. Valentini, Photocatalysis and Photodegradation of Pollutants, Nanomaterials Applications for Environmental Matrices, Elsevier. (2019) 449-488. https://doi.org/10.1016/B978-0-12-814829-7.00015-X.

[135] R. Huo, X.L. Yang, Y.Q. Liua, Y.H. Xu, Visible-light photocatalytic degradation of glyphosate over BiVO4 prepared by different co-precipitation methods, Materials Research Bulletin. 88 (2017) 56-61. https://doi.org/10.1016/j.materresbull.2016.12.012.

[136] V.K. Landge, S.H. Sonawane, M. Sivakumar, S.S. Sonawane, et al., S-scheme heterojunction $\mathrm{Bi} 2 \mathrm{O} 3-\mathrm{ZnO} /$ Bentonite clay composite with enhanced photocatalytic performance, Sustainable Energy Technologies and Assessments. 45 (2021) 101194. https://doi.org/10.1016/j.seta.2021.101194.

[137] S.P. Patil, B. Bethi, G.H. Sonawane, V.S. Shrivastava, S. Sonawane, Efficient adsorption and photocatalytic degradation of 
Rhodamine B dye over Bi2O3-bentonite nanocomposites: A kinetic study, Journal of Industrial and Engineering Chemistry. 34 (2016) 356-363. https://doi.org/10.1016/j.jiec.2015.12.002.

[138] F. He, W. Jeon, W. Choi, Photocatalytic air purification mimicking the self-cleaning process of the atmosphere, Nature Communications. 12 (2021) 2528. https://doi.org/10.1038/s41467021-22839-0.

[139] J. Wang, J. Liu, Z. Du, Z. Li, Recent advances in metal halide perovskite photocatalysts: Properties, synthesis and applications, J. Energy Chemistry. 54 (2021) 770-785.

https://doi.org/10.1016/j.jechem.2020.06.024.

[140] A. Fattahi, M.J. Arlos, L.M. Bragg, R. Liang, et al., Degradation of natural organic matter using Ag-P25 photocatalyst under continuous and periodic irradiation of 405 and $365 \mathrm{~nm}$ UV-LEDs, Journal of Environmental Chemical Engineering. 9 (2021) 104844. https://doi.org/10.1016/j.jece.2020.104844.

[141] R.W. Marino, R. Howarth, Nitrogen Fixation in Freshwater and Saline Waters, Reference Module in Earth Systems and Environmental Sciences, Elsevier. (2014). https://doi.org/10.1016/B978-0-12-409548-9.09402-1.

[142] Y. Zhao, L. Zheng, R. Shi, S. Zhang, et al., Alkali Etching of Layered Double Hydroxide Nanosheets for Enhanced Photocatalytic N2 Reduction to NH3, Advanced energy materials 10 (2020) 2002199. https://doi.org/10.1002/aenm.202002199.

[143] V.H. Nguyen, M. Mousavi, J.B. Ghasemi, Q.V. Le, S.A. Delbari, M. Shahedi Asl, M. Shokouhimehr, M. Mohammadi, Y. Azizian-Kalandaragh, A. Sabahi Namini, In situ preparation of gC3N4 nanosheet/FeOCl: Achievement and promoted photocatalytic nitrogen fixation activity, Journal of Colloid and Interface Science. 587 (2021) 538-549. https://doi.org/10.1016/j.jcis.2020.11.011.

[144] P. Qiu, C. Xu, N. Zhou, H. Chen, F. Jiang, Metal-free black phosphorus nanosheets-decorated graphitic carbon nitride nanosheets with Csingle bondP bonds for excellent photocatalytic nitrogen fixation, Applied Catalysis B: Environmental, 221 (2018) 27-35. https://doi.org/10.1016/j.apcatb.2017.09.010.

[145] N.P. Radhika, R. Selvin, R. Kakkar, A. Umar, Recent advances in nano-photocatalysts for organic synthesis, Arabian Journal of Chemistry. 12 (2019) 4550-4578. https://doi.org/10.1016/j.arabjc.2016.07.007.

[146] V.H. Nguyen, M. Mousavi, J.B. Ghasemi, Q.V. Le, S.A. Delbari, M. Shahedi Asl, M. Mohammadi, M. Shokouhimehre, A. Sabahi Namini," High-impressive separation of photoinduced charge carriers on step-scheme $\mathrm{ZnO} / \mathrm{ZnSnO} 3 /$ Carbon dots heterojunction with efficient activity in photocatalytic NH3 production, Journal of the Taiwan Institute of Chemical Engineers. 118 (2021) 140-151. https://doi.org/10.1016/j.jtice.2021.01.012.

[147] G. Dong, W. Ho, C. Wang, Selective photocatalytic N2 fixation dependent on g-C3N4 induced by nitrogen vacancies, Journal of Materials Chemistry A. 46 (2015) 23435-23441. https://doi.org/10.1039/C5TA06540B.

[148] A. Kumar, P. Raizada, P. Singh, R.V. Saini, et al., Perspective and status of polymeric graphitic carbon nitride based Z-scheme photocatalytic systems for sustainable photocatalytic water purification, Chemical Engineering Journal, 391 (2020) 123496. https://doi.org/10.1016/j.cej.2019.123496. 